\title{
Sources and atmospheric processing of organic aerosol in the Mediterranean: insights from aerosol mass spectrometer factor analysis
}

\author{
L. Hildebrandt ${ }^{1}$, E. Kostenidou ${ }^{2}$, V. A. Lanz ${ }^{3}$, A. S. H. Prevot ${ }^{3}$, U. Baltensperger ${ }^{3}$, N. Mihalopoulos ${ }^{2,4}$, \\ A. Laaksonen ${ }^{5,6}$, N. M. Donahue ${ }^{1}$, and S. N. Pandis ${ }^{1,2}$ \\ ${ }^{1}$ Center for Atmospheric Particle Studies, Carnegie Mellon University, Pittsburgh, PA, USA \\ ${ }^{2}$ Institute of Chemical Engineering and High Temperature Chemical Processes (ICE-HT), Foundation of Research and \\ Technology (FORTH), Patra, Greece \\ ${ }^{3}$ Laboratory of Atmospheric Chemistry, Paul Scherrer Institut, Villigen, Switzerland \\ ${ }^{4}$ Environmental Chemical Processes Laboratory (ECPL), University of Crete, Heraklion, Greece \\ ${ }^{5}$ Department of Applied Physics, University of Eastern Finland, Kuopio, Finland \\ ${ }^{6}$ Finnish Meteorological Institute, Helsinki, Finland
}

Received: 26 May 2011 - Published in Atmos. Chem. Phys. Discuss.: 11 July 2011

Revised: 30 November 2011 - Accepted: 2 December 2011 - Published: 13 December 2011

\begin{abstract}
Atmospheric particles were measured in the late winter (25 February-26 March 2009) at a remote coastal site on the island of Crete, Greece during the Finokalia Aerosol Measurement Experiment-2009. A quadrupole aerosol mass spectrometer (Q-AMS) was employed to quantify the sizeresolved chemical composition of non-refractory submicron aerosol, and a thermodenuder was used to analyze the organic aerosol (OA) volatility. Complementary measurements included particle size distributions from a scanning mobility particle sizer, inorganic and organic particle composition from filter analysis, air ion concentrations, $\mathrm{O}_{3}, \mathrm{NO}_{\mathrm{x}}$ and $\mathrm{NO}_{\mathrm{y}}$ concentrations, and meteorological measurements. Factor analysis was performed on the OA mass spectra, and the variability in OA composition could best be explained with three OA components. The oxygenated organic aerosol (OOA) was similar in composition and volatility to the summertime OA previously measured at this site and may represent an effective endpoint in particle-phase oxidation of organics. The two other OA components, one associated with amines (Amine-OA) and the other probably associated with the burning of olive branches (OB-OA), had very low volatility but were less oxygenated. Hydrocarbon-like organic aerosol (HOA) was not detected. The absence of OB$\mathrm{OA}$ and Amine-OA in the summer data may be due to lower emissions and/or photochemical conversion of these components to OOA.
\end{abstract}

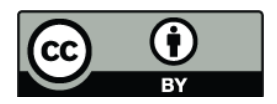

Correspondence to: S. N. Pandis (spyros@andrew.cmu.edu)

\section{Introduction}

Submicron atmospheric particles adversely affect human health (Davidson et al., 2005; Pope and Dockery, 2006) and regional visibility (Watson, 2002), and they have a highly uncertain effect on climate (IPCC, 2007). Organic aerosol (OA) constitutes a significant fraction of the submicron particle mass (Kanakidou et al., 2000; Zhang et al., 2007). Understanding the formation and concentrations of $\mathrm{OA}$ is challenging because OA has a myriad sources, its formation involves complex and poorly understood chemistry, and it is highly dynamic. After its initial formation, OA can partition between the gas and particle phases (Pankow, 1994) and can be further processed in either phase (Kalberer et al., 2004; Robinson et al., 2006; Hallquist et al., 2009). While much progress has been made in identifying and understanding these processes (Robinson et al., 2007; Hallquist et al., 2009; Jimenez et al., 2009), significant gaps remain in our understanding of the formation and transformation of $\mathrm{OA}$ in the atmosphere.

Recently, factor analysis of OA mass spectra from aerosol mass spectrometer (AMS) data has enabled separation of OA based on composition (Ulbrich et al., 2009). The results have been used to make inferences about the sources and transformation of OA in the atmosphere (Lanz et al., 2007, 2008; Hildebrandt et al., 2010a; Ulbrich et al., 2009; Morgan et al., 2010; Ng et al., 2010). At most locations, the OA can be separated into two main components: hydrocarbon-like organic aerosol (HOA), a reduced component associated with fresh emissions, and oxygenated organic aerosol (OOA), a

Published by Copernicus Publications on behalf of the European Geosciences Union. 
more oxidized component associated with OA that has been processed in the atmosphere (Zhang et al., 2007; Ng et al., 2010). Most OA in the atmosphere is usually OOA (Zhang et al., 2007; Lanz et al., 2010; Morgan et al., 2010), and hence it is especially important to understand the formation of this OA component.

The Finokalia station is an excellent location to study oxidized OA since it is isolated and therefore far from typical fresh OA sources (traffic, meat cooking, etc.). We conducted two campaigns at this site to measure OA under different photochemical conditions in the early summer (FAME-08, 8 May-5 June 2008) and the late winter (FAME09, 25 February-26 March 2009). Factor analysis of the FAME-08 OA resulted in two OOA components with different extents of oxidation but similar volatility (Hildebrandt et al., 2010a). These OOA components do not appear to correspond to different OA sources but instead to different limits of the extent of $\mathrm{OA}$ oxidation observed during the campaign (Hildebrandt et al., 2010a). Wintertime OA sampled during FAME-09 was less oxygenated and more variable in composition than summertime OA sampled during FAME-08 (Hildebrandt et al., 2010b). The differences in OA composition during the two campaigns are associated with differences in the photochemical conditions (Hildebrandt et al., 2010b). However, the bulk OA analysis does not reveal whether the FAME-09 OA was composed of less oxygenated OOA or whether it was composed of highly oxygenated OOA in addition to fresher OA components. In this manuscript we explore in more detail the composition and sources of the wintertime OA using AMS factor analysis on the organic aerosol mass spectra. We interpret the results in the context of meteorological conditions at the site and other measurements taken during the campaign, including measurements of fine and coarse particle composition from filters, aerosol size distributions and OA volatility. Our results provide insights into the sources and atmospheric processing of organic aerosol.

\section{Experimental}

The Finokalia Aerosol Measurement Experiment2009 (FAME-09) was conducted from 25 February26 March 2009 at the Finokalia Station of the Environmental Chemical Processes Laboratory of the University of Crete (Mihalopoulos et al., 1997) as part of the EUCAARI intensive winter campaign (Kulmala et al., 2009, 2011).

\subsection{Instrumentation}

The size-resolved submicron aerosol composition was measured using a quadrupole aerosol mass spectrometer (QAMS) from Aerodyne Research, Inc. (Canagaratna et al., 2007). Here we focus on the organic aerosol mass spectra, which are derived from the total aerosol mass spectra using the standard fragmentation table (Allan et al., 2004) with a few modifications, as described in the auxiliary material of Hildebrandt et al. (2010b). The particle size distribution was monitored using a scanning mobility particle sizer (SMPS, TSI classifier model 3080, CPC 3772 or 3776). The volatility of OA was analyzed using a thermodenuder (TD) system (Lee et al., 2010). Aerosol was passed alternately through the TD, heated to a predefined temperature, or a bypass line. The aerosol was sent through the same sampling line to the SMPS for online measurements of the particle size distribution and to the Q-AMS for measurements of the particle chemical composition. The volatility of the OA was determined by comparing the residual aerosol after heating in the TD to the ambient aerosol, which was passed through the bypass line.

Daily $\mathrm{PM}_{1}$ (particulate matter smaller than $1 \mu \mathrm{m}$ in diameter) and $\mathrm{PM}_{1-10}$ (larger than $1 \mu \mathrm{m}$ but smaller than $10 \mu \mathrm{m}$ in diameter) filter samples were collected using a virtual impactor (Loo and Cork, 1988). For the analysis of inorganic ions, filters were extracted with nanopure water and water-soluble ions were measured by ion chromatography (Koulouri et al., 2008; Pikridas et al., 2010). Carbonaceous material was analyzed from $\mathrm{PM}_{1}$ collected daily on quartz fiber filters. Elemental and organic carbon (EC and OC) were determined from these filters using a carbon analyzer (Sunset Laboratory Inc.) and a modification of the NIOSH thermal-optical transmission method (Koulouri et al., 2008; Pikridas et al., 2010). A number of other measurements were performed during this campaign, including air ion concentrations (Pikridas et al., 2011), aerosol light scattering and absorption, $\mathrm{O}_{3}, \mathrm{NO}_{\mathrm{x}}$ and $\mathrm{NO}_{\mathrm{y}}$ concentrations, and meteorological measurements (temperature, relative humidity and radiation intensity).

\subsection{Methods}

We categorized the air masses based on their source region using the potential emission sensitivity values (PES) of the footprint residence time plots from the FLEXPART model (Stohl et al., 1998) as described by Pikridas et al. (2010). The resulting categories, named by the region that appeared to have the major influence on air mass composition, are: Africa, Athens, Crete, Greece (after excluding Athens and Crete), marine and other continental. Athens, Crete and Greece were separated from other continental regions in order to investigate whether it is possible to detect the signature of local sources (Crete) or regional sources (Athens, Greece) at the field site. Figure 1 shows the categorized source regions for the site throughout the campaign. The most abundant source area during FAME-09 was Crete (50\%), the second most abundant was marine (15\%), and the least abundant was Africa (6\%). It is often not clear whether the major influence was marine, Crete or Africa. As a result, the dust storm period (7-9 March) when $\mathrm{PM}_{10}$ concentrations were 


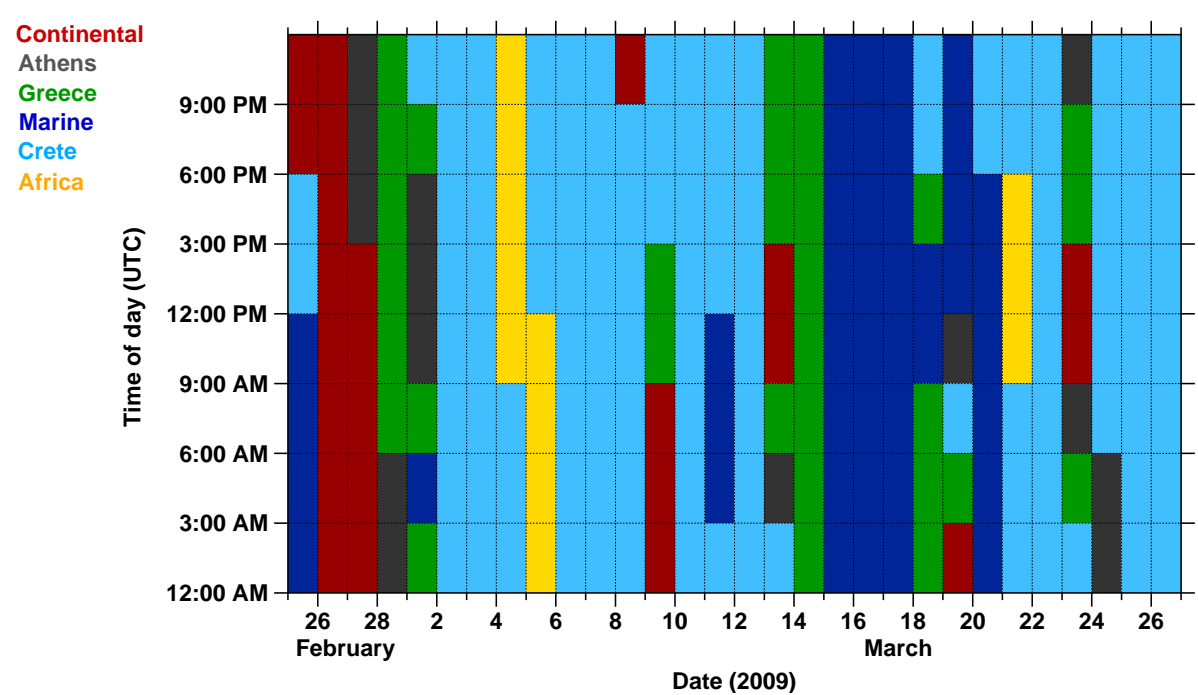

Fig. 1. Results of the source region analysis based on the FLEXPART footprint residence time plots (Stohl et al., 1998; Pikridas et al., 2010).

high is in the Crete category, whereas $\mathrm{PM}_{10}$ concentrations were low in the Africa category.

We applied positive matrix factorization (PMF) to the time series of the organic aerosol mass spectra from the Q-AMS, using the PMF2 algorithm (version 4.2) by P. Paatero to solve the bilinear unmixing problem (Paatero and Tapper, 1994). We examined different PMF solutions (varying the number of factors and other PMF settings) and evaluated them with respect to ancillary data (data not included in the PMF analysis, e.g., sulfate measurements) and mathematical diagnostics, as described in more detail in the Appendix. In order to examine whether the OA factors exhibited statistically significant diurnal variation, we conducted one-way analysis of variance (ANOVA) tests with factor concentrations and total $\mathrm{OA}$ as dependent variables and time of day as the independent variable (Hildebrandt et al., 2010a). Before conducting ANOVA, we removed the data points when the aerosol was clearly influenced by fire plumes (7, 24 and 26 March) so that OA spikes associated with the fire plumes do not mask the diurnal cycle.

\section{Analyzing OA volatility using thermodenuder data}

The AMS collection efficiency (CE) was estimated for the ambient aerosol and the thermodenuded aerosol using the algorithm of Kostenidou et al. (2007), as in our previous study (Lee et al., 2010), to account for potential changes in the CE upon heating and evaporating part of the particle mass. The $\mathrm{CE}$ of the ambient aerosol ranged from 0.5 to 0.85 (average $=0.6$ ), the $\mathrm{CE}$ of the thermodenuded OA ranged from 0.4 to 0.75 (average $=0.6$ ), and we applied the estimated timedependent CE to all data. The lower CE during FAME-09 compared to FAME-08 (average ambient $\mathrm{CE}=0.85$, Lee et al., 2010) may be due to differences in aerosol composition or to the fact that different Q-AMS instruments were used for these two campaigns. The TD data were also corrected for particle losses in the TD, which depend on particle size, thermodenuder temperature and residence time, and which were determined in calibration experiments (Lee, 2010). During six days of the campaign (6-12 March), SMPS data were not available, and the $\mathrm{CE}$ and particle losses could not be estimated for this time period. We do not use the data from these days to analyze the OA volatility. We do use the data for ambient OA analysis after correcting the data with the campaign-average ambient $\mathrm{CE}$.

The concentrations of the OA factors were often low and close to the detection limit of the AMS. For the TD analysis, we therefore eliminated all data points when the ambient factor concentrations were below $0.2 \mu \mathrm{g} \mathrm{m}^{-3}$, a reasonable estimate for the detection limit of the Q-AMS (Drewnick et al., 2009). We analyzed the volatility of the different OA components by first computing their mass fraction remaining (MFR, the ratio of the thermodenuded organic mass to the ambient organic mass). We kept the thermodenuder at a temperature of approximately $100^{\circ} \mathrm{C}$ for most of FAME-09 to be able to observe changes in the OA volatility over the course of the campaign. We also varied the TD temperature during some parts of the campaign to be able to construct thermograms (MFR as a function of TD temperature) of the OA (Lee et al., 2010). We can use these data and the organic aerosol evaporation model (Lee et al., 2010; Riipinen et al., 2010) to estimate OA volatility. Considering the large uncertainty in estimating OA volatility distributions (Lee et al., 2010) we here limit the analysis to comparing the volatility of the FAME-09 OA to the volatility of the FAME-08 OA.

The base-case volatility basis set used to estimate the FAME-08 OA volatility consisted of four saturation mass concentrations $\left(C^{*}\right)$ of $0.01,0.11$ and $10 \mu \mathrm{g} \mathrm{m}^{-3}$, abbreviated as $\left[\begin{array}{llll}0.01 & 0.1 & 1 & 10\end{array}\right]$; the corresponding mass fraction 

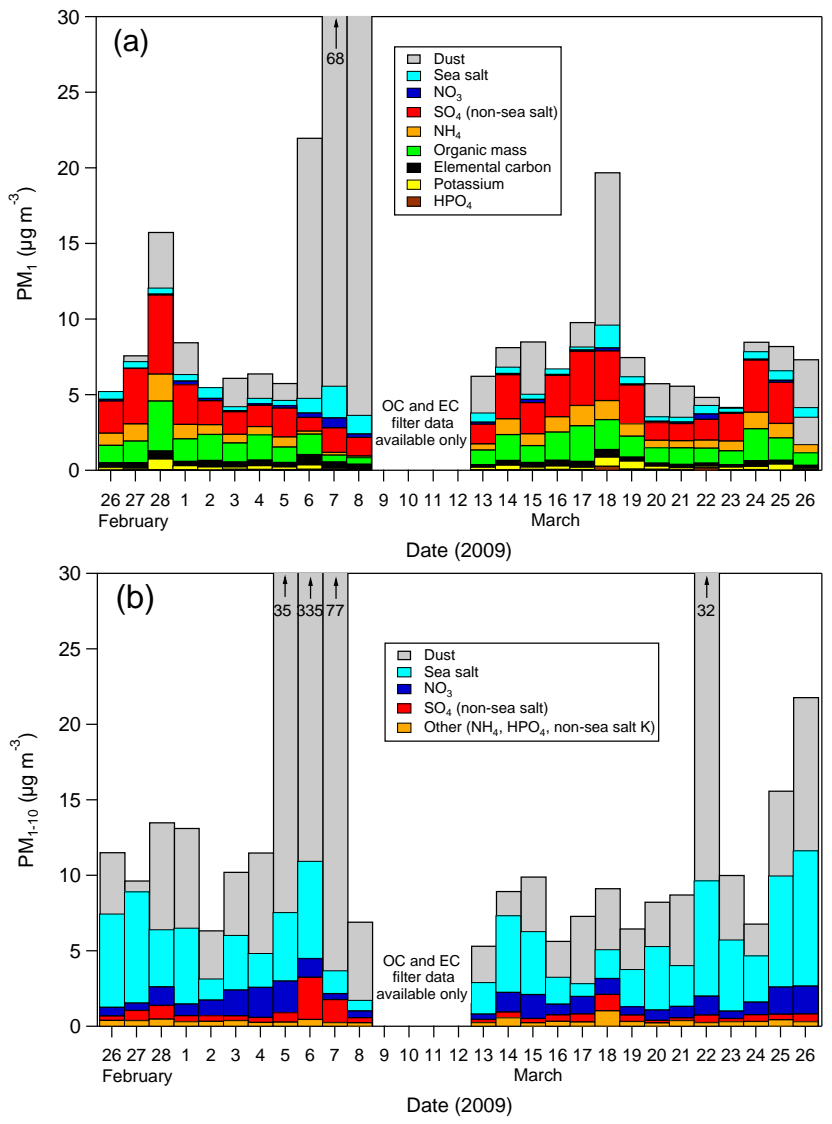

Fig. 2. Filter composition of fine PM (a) and coarse PM (b) measured during FAME-09. Fine PM is dominated by organics, sulfate and ammonium, often with significant contributions from dust. Coarse PM is dominated by sea salt, dust and nitrate with a smaller contribution from non-sea salt sulfate.

values were estimated as [0.2 0.2 0.3 0.3] (Lee et al., 2010). In order to compare this volatility to the FAME-09 OA volatility, we use the aerosol evaporation model with the same effective mass accommodation coefficient and vaporization enthalpy as for the FAME-08 base case $(0.05$ and $80 \mathrm{~kJ} \mathrm{~mol}^{-1}$, respectively). We set the volatility basis set as $s \times\left[\begin{array}{llll}0.01 & 0.1 & 1 & 10\end{array}\right]$ where $s$ is a multiplicative "shifting factor" from the FAME-08 volatility basis set. We fix the mass fraction values to the values estimated for FAME-08 and use the evaporation model to calculate the shifting factor while minimizing the residuals between measured and modeled MFR. The evaporation model accounts for differences between the two campaigns in OA concentrations, particle size distributions and thermodenuder residence times. Thus, the analysis conducted here is more rigorous and more accurate than a comparison of thermograms collected during the two campaigns.

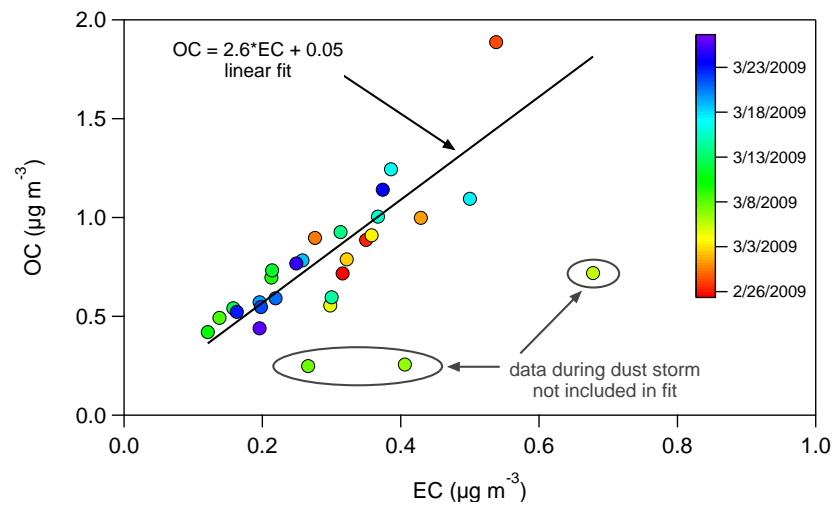

Fig. 3. Correlation of organic carbon (OC) and elemental carbon (EC) measured during the campaign for $\mathrm{PM}_{1}$. Data points are colored by time during the campaign. The OC:EC ratio during the dust storm period was lower than during the rest of the campaign, and these points were not included in the linear fit. Overall, the OC:EC ratio was much lower than during the summer, consistent with less photochemical oxidation.

\section{Results and discussion}

\subsection{Filter measurements and meteorological conditions}

A summary of the filter measurements is presented in Fig. 2 for fine $\mathrm{PM}\left(\mathrm{PM}_{1}\right.$, panel a) and coarse PM ( $\mathrm{PM}_{1-10}$, panel b). During 7-9 March, the area experienced a dust storm resulting in $\mathrm{PM}_{10}$ concentrations exceeding $500 \mu \mathrm{g} \mathrm{m}^{-3}$ at times (data from an aerodynamic particle sizer, not shown). Outside of the dust-storm period, fine PM was usually dominated by ammonium, sulfate, and organics, consistent with the AMS data during this time period (Hildebrandt et al., 2010b) and also with previous studies at Finokalia (Koulouri et al., 2008; Pikridas et al., 2010). Organic mass from the filter samples was estimated by multiplying filter measurements of organic carbon by the ratio of organic mass to organic carbon (OM:OC). The OM:OC ratio was estimated from AMS measurements of $f_{44}$ (the fraction of total OA mass due to fragments at $m / z$ 44) using the correlations developed by Aiken et al. (2008). The campaign-average estimated OM:OC ratio was 1.8; daily averages ranged from 1.6 to 1.9. AMS measurements of organic mass agreed well with filter measurements (slope $=1.0, R^{2}=0.79$ ); AMS measurements of sulfate mass agreed reasonably well with filter measurements (slope $=0.63, \mathrm{R}^{2}=0.54$ ). It is possible that this slope is less than 1 and the correlation is weaker because of the lower size cutoff of the AMS and the significant sulfate concentrations above $\sim 0.7 \mu \mathrm{m}$. Sulfate concentrations attributable to sea salt (which is not detected by the Q-AMS) were only $0.05 \mathrm{\mu g} \mathrm{m}^{-3}$ on average and therefore do not affect the slope significantly. Measured $\mathrm{Na}^{+}$concentrations correlated well with $\mathrm{Cl}^{-}\left(R^{2}=0.73\right)$, suggesting a common origin (sea salt). Thus, sea salt concentrations were approximated 
based on sea water composition and the measured concentrations of $\mathrm{Na}^{+}, \mathrm{Cl}^{-}, \mathrm{Mg}^{2+}, \mathrm{K}^{+}, \mathrm{Ca}^{2+}$ and $\mathrm{SO}_{4}^{2-}$ as in previous work (Sciare et al., 2005). Dust concentrations in the fine and coarse mode were not measured explicitly but were estimated as the sum of the non-speciated PM and $\mathrm{Ca}^{2+}$ not attributed to sea salt. Based on this method, fine PM appears to have a significant contribution from dust during most days of the campaign.

The coarse-mode composition was dominated by dust, sea salt and nitrate, with a smaller contribution from $\mathrm{SO}_{4}^{2-}$ not associated with sea salt. Measured concentrations of $\mathrm{Na}^{+}$correlated well with $\mathrm{Mg}^{2+}\left(R^{2}=0.89\right)$ and with $\mathrm{Cl}^{-}$ $\left(R^{2}=0.91\right)$, confirming a common origin (sea salt), and $\mathrm{PM}_{1-10}$ sea salt concentrations were approximated according to Sciare et al. (2005). The average $\mathrm{Cl}^{-} / \mathrm{Na}^{+}$mass ratio was equal to 1.45 , a bit lower than the typical ratio of 1.8 reported for sea water (Seinfeld and Pandis, 2006). Lower $\mathrm{Cl}^{-} / \mathrm{Na}^{+}$mass ratios have been observed in previous studies at this site (Sciare et al., 2005; Pikridas et al., 2010), and they are due to reactions of nitric and sulfuric acid with $\mathrm{NaCl}$ and subsequent release of $\mathrm{HCl}$.

The ratio of organic carbon to elemental carbon (OC:EC) in fine PM can be an indicator of photochemical activity during the campaign (Cabada et al., 2004). The OC:EC slope of 2.6 (Fig. 3) obtained from filter measurements suggests moderate photochemical activity during this campaign - much less than during the summer when the OC:EC slope was 5.4 (Pikridas et al., 2010). This is consistent with the analysis of the AMS mass spectra, which indicated significantly less oxidized organic aerosol during FAME-09 (Hildebrandt et al., 2010b). During the dust storm the OC:EC ratio is lower, consistent with less atmospheric processing or fresher emissions. This was also observed during the summer campaign (Pikridas et al., 2010) and is attributed to the influence of major cities in Africa or interference of crustal elements in the EC analysis.

We used meteorological measurements taken at the site and data from the European Centre for MediumRange Weather Forecasts (www.ecmwf.int/research/era/do/ get/era-interim) to evaluate the photochemical conditions at the site. The conditions were significantly different during the first few days of the campaign (25-28 February) compared to the campaign-average conditions. The average solar radiation measured at the site was lower during those days: $75 \mathrm{~W} \mathrm{~m}^{-2}$ compared to the campaign-average of $175 \mathrm{~W} \mathrm{~m}^{-2}$. According to the ECMWF, the average low cloud cover in the grid cell containing the site (see Fig. S1 in Hildebrandt et al., 2010b) was 0.56 from 25-28 February, compared to the campaign-average of 0.16 . This difference in photochemical conditions presents a unique opportunity to evaluate the effect of photochemistry on aerosol composition. The relative humidity was also higher during the first few days - the 2528 February average was $82 \%$ compared to the campaignaverage of $73 \%$.

\subsection{Aerosol size distribution}

During FAME-09, the aerosol size distribution was more variable than during the summer campaign (Pikridas et al., 2010), primarily due to the higher frequency of nucleation events during FAME-09 (Pikridas et al., 2011) and the more variable meteorological conditions. Figure 4 shows the campaign-average number and volume size distributions for FAME-09 and their standard deviations. The average number size distribution for FAME-09 was bimodal with the dominant mode located at $50 \mathrm{~nm}$, differently from FAME-08 when the number size distribution only had one mode located at $90 \mathrm{~nm}$ (Pikridas et al., 2010). The volume distribution during FAME-09 was centered at $230 \mathrm{~nm}$, compared to $300 \mathrm{~nm}$ during FAME-08 (Pikridas et al., 2010).

The FAME-09 time series of total particle concentrations from the SMPS (particle mobility diameter $15 \mathrm{~nm}-500 \mathrm{~nm}$ ) and the concentration of particles smaller than $30 \mathrm{~nm}$ in diameter are shown in Fig. 5. The figure also indicates the times when nucleation events were identified based on the increase in concentrations of air ions between $2 \mathrm{~nm}$ and $10 \mathrm{~nm}$ in diameter (Pikridas et al., 2011), and when small agricultural fires were observed from the field site. Nucleation events are clearly distinguishable from the influence of fires; while nucleation events resulted in an increase in mostly small particles $\left(15 \mathrm{~nm}<D_{\mathrm{p}}<30 \mathrm{~nm}\right)$ which lasted for several hours, the influence of the fires was usually in the form of a spike in total particle number, not in the number of small particles. Even though the fires associated with these spikes appear to be local, the small particles which are emitted appear to coagulate, grow or even evaporate quickly. The delay between the nucleation events identified based on increases in air ion concentrations $(2-10 \mathrm{~nm})$ and the increase in particle concentrations from the SMPS $(>15 \mathrm{~nm})$ is probably due to growth of the particles to the SMPS size range.

\subsection{Results and interpretation of Positive Matrix Fac- torization (PMF) analysis}

We here focus on the 3-factor PMF solution, which best represents our data as explained in the Appendix. The mass spectra and time series of the three factors (OA components) are presented in Figs. 6 and 7, respectively. The first factor is dominated by fragments at mass-to-charge ratio $(\mathrm{m} / \mathrm{z}) 58$ and also has a significant (but much smaller) contribution at $m / z$ 86. These fragments are likely due to amine functional groups: the fragment at $m / z 58$, most likely $\mathrm{C}_{3} \mathrm{H}_{8} \mathrm{~N}^{+}$, is associated with trimethylamine, and $m / z 86$, probably $\mathrm{C}_{5} \mathrm{H}_{12} \mathrm{~N}^{+}$, can originate from triethylamine and diethylamine salts $(\mathrm{Ge}$ et al., 2011a). This is also consistent with speciation studies at Finokalia, which reveal the presence of amines there (Violaki and Mihalopoulos, 2010). We therefore name the first factor Amine-OA. Spikes in the concentrations of the second factor were associated with the observation of small fires close to the measurement site (Fig. 7), most likely the 

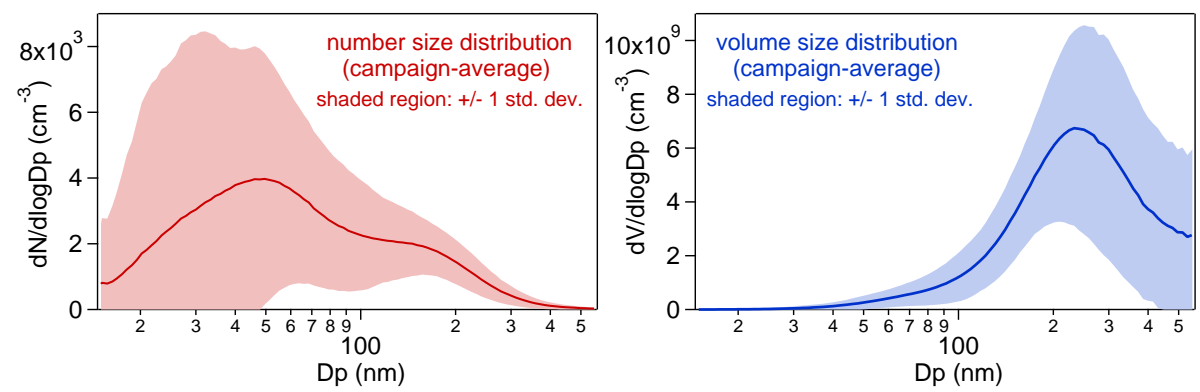

Fig. 4. Campaign-average number (left) and volume (right) size distributions for FAME-09. The particle size distributions were more variable and the particles were smaller on average during FAME-09 than during FAME-08.
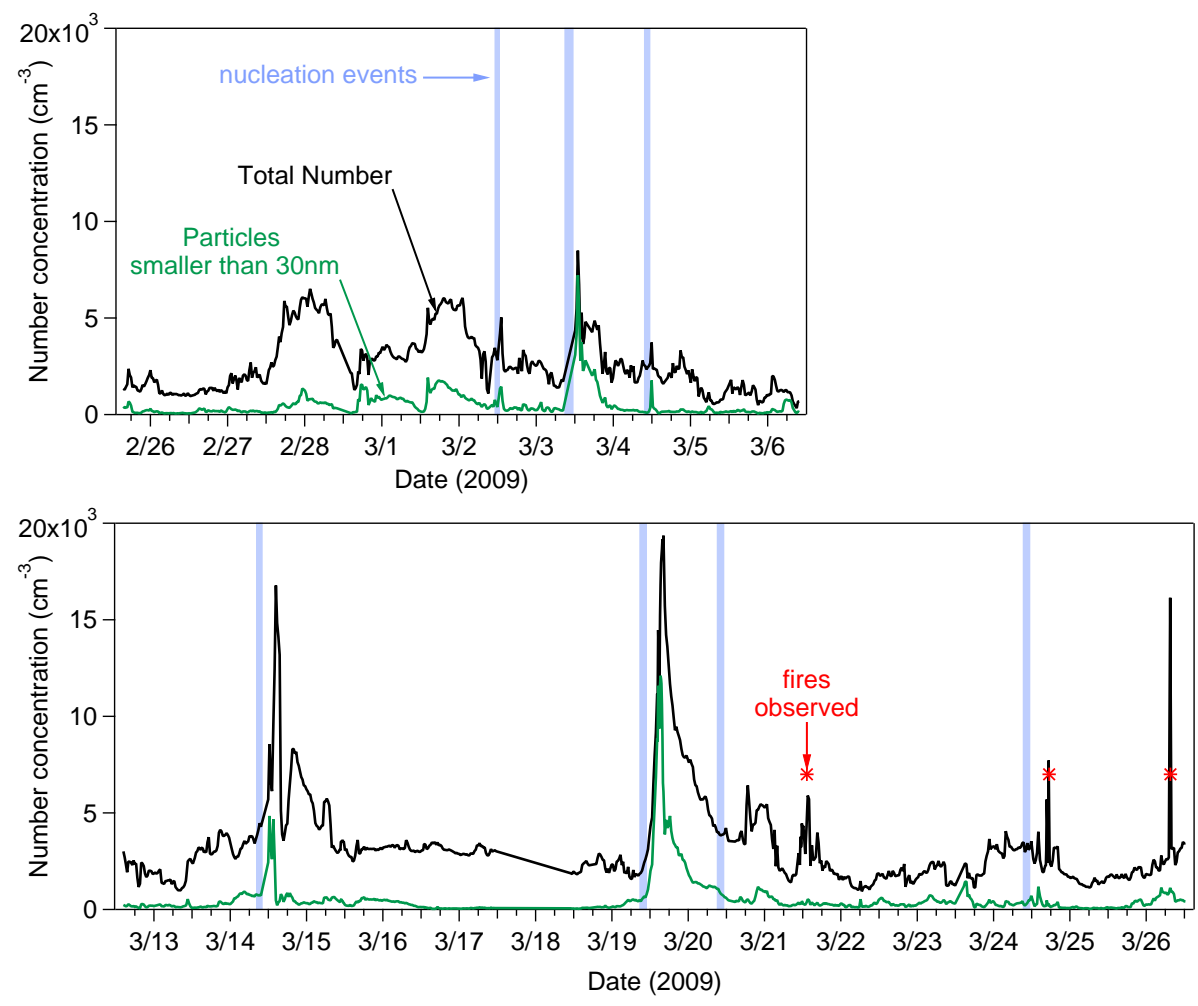

Fig. 5. Time series of total particle number $\left(15 \mathrm{~nm}<D_{\mathrm{p}}<500 \mathrm{~nm}\right.$, black line $)$ and particles smaller than $30 \mathrm{~nm}\left(15 \mathrm{~nm}<D_{\mathrm{p}}<30 \mathrm{~nm}\right.$, green line) measured by the SMPS. Nucleation events (light blue bands) were identified based on increases in the concentration of air ions $\left(2 \mathrm{~nm}<D_{\mathrm{p}}<10 \mathrm{~nm}\right.$, Pikridas et al., 2011). The time delay between nucleation events and the increase in SMPS particle concentrations is likely due to growth of the particles to the SMPS size range. On 24 March, the nucleated particles did not grow to the SMPS size range. Fires observed from the field site (red stars) are characterized by increases in the concentration of larger particles. SMPS data were not available on 6-12 March.

private burning of olive branches, which is common at this time of the year throughout Greece and the Balkans. However, the profile of the factor does not resemble biomass burning organic aerosol, BBOA (Ng et al., 2011), and we therefore name this factor OB-OA (Olive branch burning OA) to avoid confusion with more typically observed BBOA. The third PMF factor resembles oxygenated organic aerosol (OOA), a factor extracted in all PMF analysis ( $\mathrm{Ng}$ et al., 2011) and typically associated with OA that has been pro- cessed in the atmosphere. We note that the spikes in OB-OA, likely associated with the burning of olive branches, are also visible in the concentration of OOA. This is consistent with gaseous emissions from the burning of olive branches aiding in the formation of OOA and with the rapid conversion of fresh OB-OA to OOA. The average concentrations of these factors and their contribution to total OA in air masses from the different source regions are summarized in Table 1 . The OOA factor always accounts for more than $50 \%$ of the OA 
Table 1. Contributions of OA components by source region.

\begin{tabular}{lcccccc}
\hline & $\begin{array}{c}\text { Marine } \\
(n=227)\end{array}$ & $\begin{array}{c}\text { Africa } \\
(n=86)\end{array}$ & $\begin{array}{c}\text { Crete } \\
(n=764)\end{array}$ & $\begin{array}{c}\text { Athens } \\
(n=11)\end{array}$ & $\begin{array}{c}\text { Greece } \\
(n=188)\end{array}$ & $\begin{array}{c}\text { Continental, other } \\
(n=159)\end{array}$ \\
\hline Amine-OA $\left(\mu \mathrm{g} \mathrm{m}^{-3}\right)$ & 0.05 & 0.05 & 0.07 & 0.18 & 0.17 & 0.16 \\
Amine-OA/total OA & 0.06 & 0.07 & 0.11 & 0.14 & 0.18 & 0.21 \\
OB-OA $\left(\mu \mathrm{g} \mathrm{m}^{-3}\right)$ & 0.14 & 0.24 & 0.18 & 0.27 & 0.18 & 0.17 \\
OB-OA/total OA & 0.15 & 0.35 & 0.26 & 0.22 & 0.19 & 0.22 \\
OOA $\left(\mu \mathrm{g} \mathrm{m}^{-3}\right)$ & 0.70 & 0.41 & 0.43 & 0.76 & 0.60 & 0.43 \\
OOA/total OA & 0.79 & 0.58 & 0.63 & 0.63 & 0.64 & 0.56 \\
\hline
\end{tabular}

mass, while the OB-OA factor usually accounts for most of the rest. Correlations of the factor time series with ancillary data are summarized in Table A2 and discussed in more detail in Sects. 3.3.1-3.3.3 below.

The concentrations of total OA, OOA and OB-OA exhibited statistically significant diurnal variation $(p=0.007$, $0.02,0.007$, respectively), and the diurnal cycles of their average concentrations are presented in Fig. 8, along with the diurnal cycle of the average ozone concentration. We split the Amine-OA data into two periods: the first week (until noon on 3 March) and the rest of the campaign. The AmineOA concentrations were much higher during the first week and did not exhibit statistically significant diurnal variation ( $p=0.42$ ). During 3-26 March, Amine-OA concentrations were very low, and they did exhibit statistically significant diurnal variation $\left(p=1 \times 10^{-5}\right.$, Fig. 8). The diurnal cycle of the different OA factors is discussed in more detail in the following sections.

\subsubsection{Amine-OA}

Amine-OA was not detected elsewhere in Europe during the EUCAARI intensive periods (Prevot et al., 2011). However, fragments associated with amine functional groups have been identified in AMS data from other locations (Takami et al., 2005; Sun et al., 2011). While the signal of amine functional groups can be enhanced in the AMS due to surface ionization, we did not observe this effect (Hildebrandt et al., 2010b). Figure 9 shows the Amine-OA concentration during the first week of FAME-09, colored by source region, as well as total aerosol number concentrations from the SMPS. The Amine-OA concentration is not correlated to total particle number $\left(R^{2}=0.00\right.$, Table A2). Hence, the Amine-OA is likely not associated with local or regional combustion sources, as further confirmed by the lack of significant correlation between the Amine-OA and typical fresh combustion tracers such as EC and $\mathrm{NO}_{\mathrm{x}}$ (CO measurements were not available for this campaign). The Amine-OA also does not seem to be linked to sea salt since the filter measurements (Fig. 2) suggest that sea salt concentrations were not higher during the first week compared to the rest of the campaign.
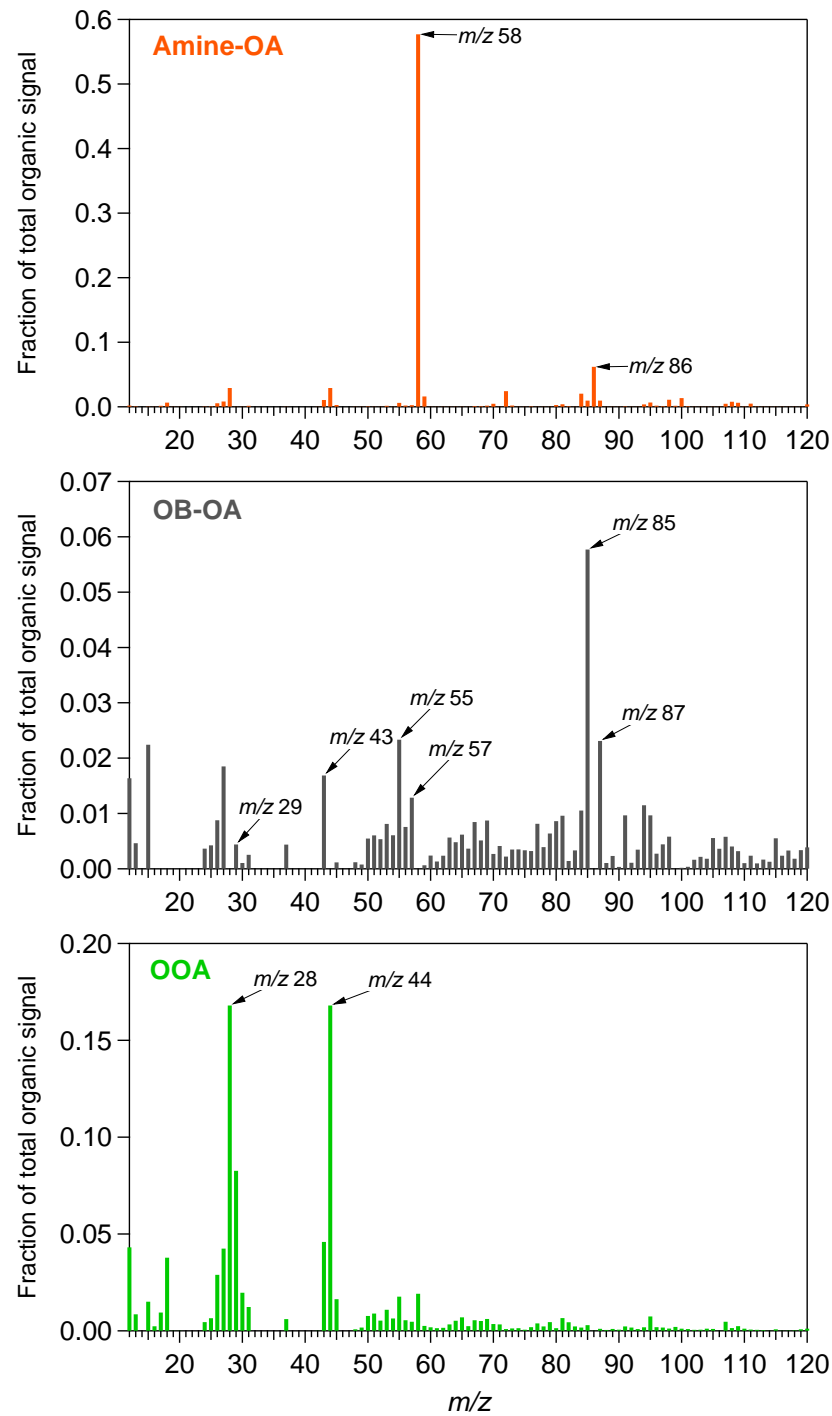

Fig. 6. Mass spectra of $\mathrm{OA}$ components from the 3-factor PMF solution. The signals at $m / z, 28$ and $m / z, 44$ are equal by definition in the organic fragmentation table. 

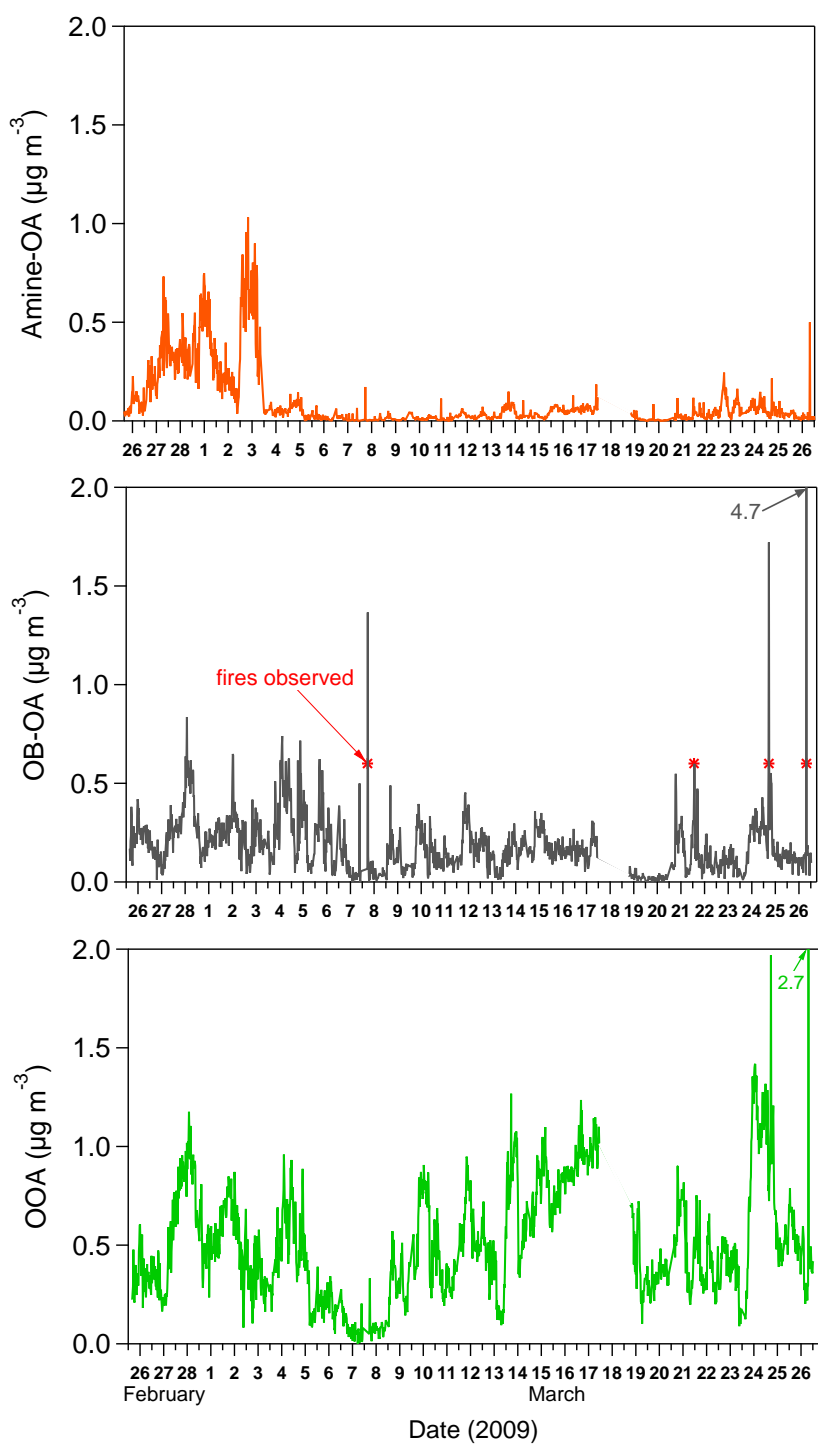

Fig. 7. Time series of OA components from the 3-factor PMF solution. OOA was the most abundant OA component. OB-OA spiked when fires were observed from the field site. Amine-OA was more abundant during the first few days of the campaign when meteorological conditions were milder.

When averaging over the entire campaign, Amine-OA concentrations were higher from Greece and the "other continental" source region than from Africa or the marine source region (Table 1). However, this does not necessarily imply that the Amine-OA is associated with Greece, for example, as the concentrations were much lower when the air originated from Greece later in the campaign. Instead, the higher Amine-OA concentrations appear to be associated with the different meteorological conditions during the first few days of the campaign: lower solar radiation, and higher cloud cover and RH (Sect. 3.1). There was also a significant contribution from the Amine-OA during 1-4 March when solar ra-

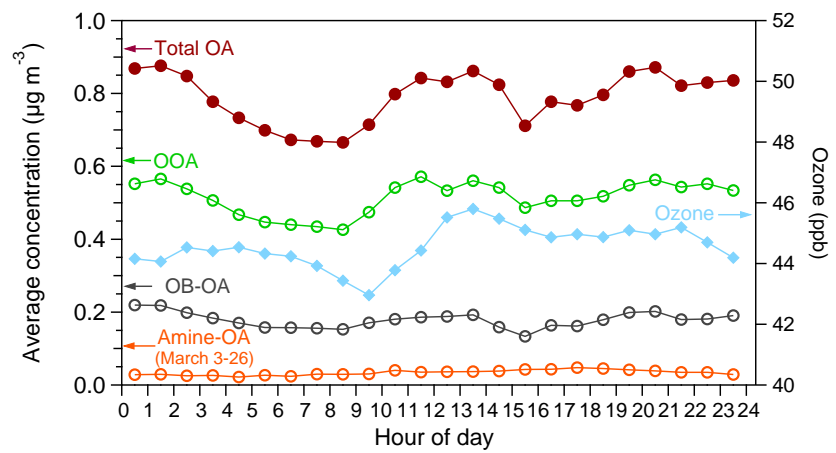

Fig. 8. Diurnal cycles of total OA and OA component concentrations (left vertical axis) and of the ozone concentrations (right vertical axis). Ozone and OOA follow similar diurnal cycles.

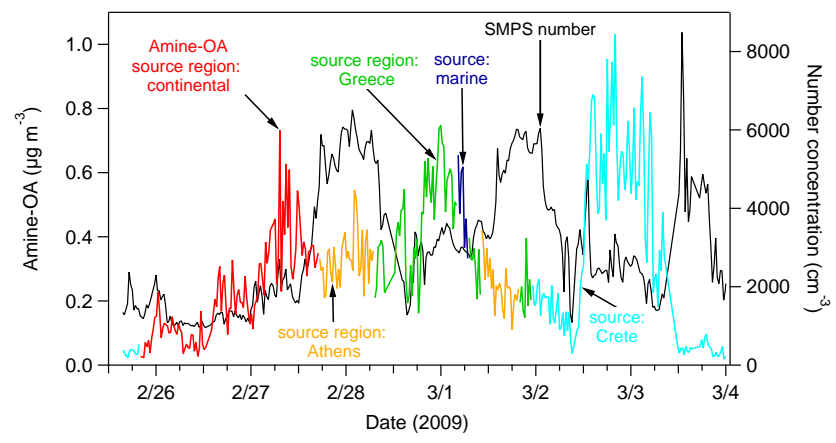

Fig. 9. Zoom of Amine-OA time series (left vertical axis) colored by the source region categorized as explained in the text. SMPS number concentrations (right vertical axis) do not correlate with Amine-OA concentrations.

diation measured at the site was higher (average $211 \mathrm{~W} \mathrm{~m}^{-2}$ ). However, during 1-4 March the Amine-OA concentrations peak during the night (Fig. 9), consistent with an association between Amine-OA concentrations and a dearth of solar radiation and/or abundance of clouds. Plausible explanations for these observations include that (1) the cloudy and nighttime conditions prevent quick and efficient degradation of Amine-OA by photochemical oxidation, (2) the presence of Amine-OA is associated with cloud processing (Rehbein et al., 2011), and (3) the Amine-OA is associated with the formation of particulate aminium salts from trimethylamine (or other amines), which is favored under conditions of higher RH (Ge et al., 2011b). These explanations are consistent with our observation that during FAME-08, under different meteorological conditions (lower RH, much lower cloud cover and much higher photochemical activity) no Amine-OA factor was detected at the same location (Hildebrandt et al., 2010a).

We obtain a measure of the Amine-OA volatility by averaging its MFR at a thermodenuder residence time of $30 \mathrm{~s}$ over temperatures of $85^{\circ} \mathrm{C}-115^{\circ} \mathrm{C}$, at which most of the data were collected. The average MFR is 1 (Amine-OA did 
not evaporate significantly in our thermodenuder), suggesting that the Amine-OA has very low volatility. This is consistent with the findings of recent laboratory experiments, which suggested that aminium salts are less volatile than ammonium sulfate (Smith et al., 2010).

\subsubsection{OB-OA}

The OB-OA is characterized by high contributions from $\mathrm{m} / \mathrm{z} 27,29,43,55,85$ and 87 , as well as significant contributions at high $\mathrm{m} / z$ (50\% of the organic mass at $\mathrm{m} / z>120$ ), which is not typically observed in AMS spectra of ambient $\mathrm{OA}$. The OB-OA mass spectrum does not resemble the mass spectra of humic or fulvic acid (Alfarra, 2004) and therefore likely does not represent a humic-like substance. Even though the diurnal variation of the OB-OA is statistically significant (Fig. 8), the variation is small, and we do not expect to be able to explain it with meteorological or photochemical conditions considering that the factor appears to be associated with the burning of olive tree branches.

Potassium emissions are often associated with biomassrelated fires. Here we use the AMS signal at $\mathrm{m} / \mathrm{z} 39$ as a proxy for potassium and therefore a tracer of fires. This assumes that the signal of $\mathrm{C}_{3} \mathrm{H}_{3}^{+}$is negligible compared to the signal of potassium, a reasonable assumption considering the high total signal at $\mathrm{m} / \mathrm{z}, 39$ (nominally $\sim 50 \mu \mathrm{g} \mathrm{\textrm {m } ^ { - 3 }}$ on average). The signal of potassium is enhanced in the AMS due to surface ionization and hence the absolute AMSpotassium measurements are not reliable; however, the relative values are still informative. We find a strong correlation between the concentrations of OB-OA and AMS-potassium $\left(R^{2}=0.57\right)$, further confirming that this $\mathrm{OA}$ is associated with fires. The OB-OA is also correlated with EC concentrations $\left(R^{2}=0.28\right)$ as expected for incomplete combustion emissions.

Most of the fires influencing the observed OA are not local. Figure 10 shows a time series of OB-OA for the first eight days of the campaign, colored by source region, and the time series of total particle number from the SMPS. OBOA concentrations can be relatively high for essentially all source regions. For example, on 28 February OB-OA concentrations were elevated when the air mass originated from Athens and Greece. The OB-OA on 4 March might be due to fires on Crete; however, they are likely not local fires since the increase in OB-OA was not associated with an increase in particle number concentration. While the local fires are reflected by spikes in the OB-OA, the regional fires are represented by longer periods of elevated OB-OA concentrations.

Similarly to the Amine-OA, the OB-OA did not evaporate significantly in our thermodenuder. At a thermodenuder residence time of $40 \mathrm{~s}$, the mass fraction remaining of the OB$\mathrm{OA}$ averaged over all data at TD temperatures ranging from $85^{\circ} \mathrm{C}$ to $115^{\circ} \mathrm{C}$ was 1 . There was no significant difference in the mass fraction remaining from the different periods in Fig. 10. The signal at $m / z 85$ and $m / z, 87$ (Fig. 6) may be

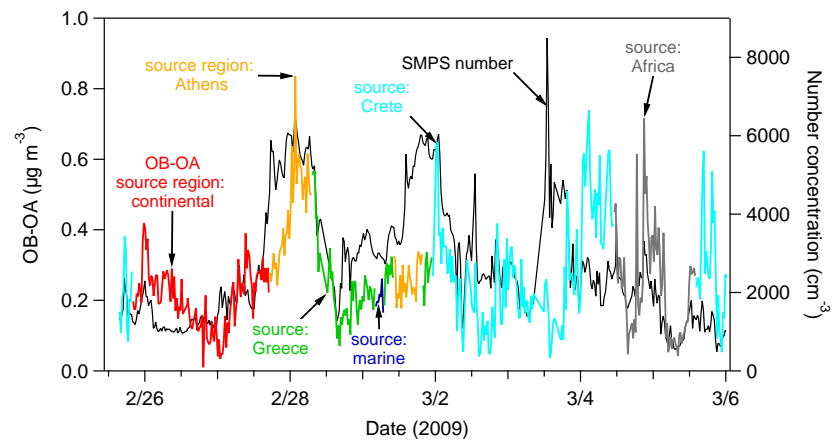

Fig. 10. Zoom of OB-OA time series (left vertical axis) colored by the source region categorized as explained in the text. SMPS number concentrations (right vertical axis) do not correlate with OB-OA concentrations.

due to amine functional groups; hence, the low volatility of the OB-OA may be associated with the stabilizing effects of amines (Smith et al., 2010).

The OB-OA mass spectrum also has significant contributions from ions at $m / z 55$ and 57, fragments typically associated with HOA. However, the contributions of $\mathrm{m} / z 55$ and 57 appear to be due to organic fragments associated with fires, not due to a hidden HOA factor, as explained in more detail in the Appendix. Methods to estimate the contribution of HOA (Ng et al., 2011) result in average values between $-0.07 \mu \mathrm{g} \mathrm{m}^{-3}$ and $-0.03 \mu \mathrm{g} \mathrm{m}^{-3}$, suggesting that HOA concentrations were close to zero and that the estimation methods may not be appropriate at very low concentrations. Thus, just like during the summer campaign (Hildebrandt et al., 2010a), HOA was not present in significant concentrations during FAME-09. A plausible explanation for the lack of observed HOA during this study is evaporation. While HOA has been shown to exhibit significant volatility (Robinson et al., 2007; Huffman et al., 2009), the Amine-OA and OB-OA observed here are practically non-volatile within the error of our measurements. Thus, HOA may evaporate by the time it reaches the site while OB-OA and Amine-OA do not.

\subsubsection{OOA}

OOA was the most abundant factor, as expected for a remote site. The diurnal cycle of OOA was similar to that of total OA and ozone and can be explained by meteorology and photochemical conditions: concentrations were lowest in the early morning, peaked in the early afternoon and then decreased slightly before rising again in the evening. The peak in the early afternoon is most likely associated with photooxidation. The rise in the evening may be associated with changes in the boundary layer height. Highly oxidized OOA (also referred to as OOA-1 or LV-OOA) is typically correlated with sulfate $\left(\mathrm{SO}_{4}^{2-}\right)$ concentrations (Lanz et al., 2007; Ulbrich et al., 2009; Hildebrandt et al., 2010a), and less oxidized OOA (also referred to as OOA-2 or SV-OOA) is 


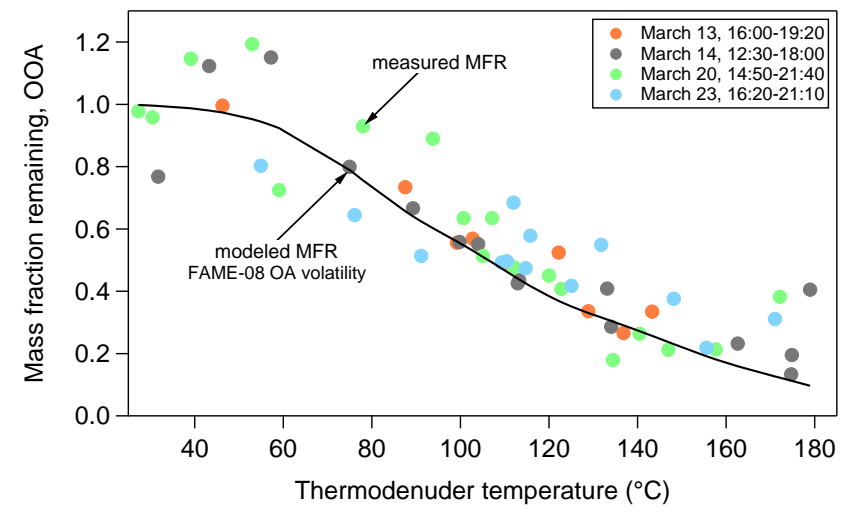

Fig. 11. Measured (circles) and modeled (line) OOA mass fraction remaining (MFR) as a function of thermodenuder temperature. The modeled MFR is obtained using the FAME-08 OA volatility and the aerosol evaporation model. The volatility of the OOA measured during FAME-09 is the same as the volatility of the OA (all OOA) measured during FAME-08.

typically correlated with nitrate $\left(\mathrm{NO}_{3}^{-}\right)$concentrations (Lanz et al., 2007; Ulbrich et al., 2009). The OOA measured here is similarly correlated with $\mathrm{SO}_{4}^{2-}\left(R^{2}=0.54\right)$ and $\mathrm{NH}_{4}^{+}$ $\left(R^{2}=0.58\right)$; concentrations of $\mathrm{NO}_{3}^{-}$in $\mathrm{PM}_{1}$ were very low throughout the campaign.

The OOA is the only component of the OA sampled during FAME-09 that exhibited a semi-volatile nature. Figure 11 shows four OOA thermograms obtained during different times of the campaign when we varied the TD temperature. We used these data to calculate the shifting factor relative to the FAME-08 OA volatility as explained in Sect. 2.2. The calculated shifting factor is 1.0 - within the error of our measurements, the volatility of OOA during FAME-09 is the same as the volatility of OA (entirely OOA) during FAME08. Furthermore, the mass spectrum of the FAME-09 OOA is similar to the mass spectrum of the FAME-08 OOA. We here summarize the mass spectrum with $f_{43}$ and $f_{44}$, the fraction of total OA mass due to fragments at $m / z 43$ and $\mathrm{m} / \mathrm{z} 44$, respectively. The OOA components extracted from different field campaigns are not expected to be identical since PMF analysis simply separates OA into those components that best explain the OA variability. However, $f_{43}$ and $f_{44}$ can still be used to characterize the extent of oxidation of the OOA $(\mathrm{Ng}$ et al., 2010). In the FAME-09 OOA, $f_{43}$ was $4.6 \%$ and $f_{44}$ was $16.8 \%$. In the FAME-08 OA, one of the OOA components exhibited $f_{43}=6.5 \%$ and $f_{44}=13.1 \%$; the other OOA component exhibited $f_{43}=4.5 \%$ and $f_{44}=21.7 \%$. Thus, the extent of oxidation of the FAME-09 OOA was intermediate between the extents of oxidation of the two OOA factors extracted from the FAME-08 OA, and it was very similar to the average extent of oxidation of the FAME-08 $\mathrm{OA}\left(f_{43}=5.3 \%\right.$ and $\left.f_{44}=18.2 \%\right)$. Thus, we find that OOA observed during the winter (FAME-09) is similar to the OOA observed during the summer (FAME-08) in terms of volatility and extent of oxidation.

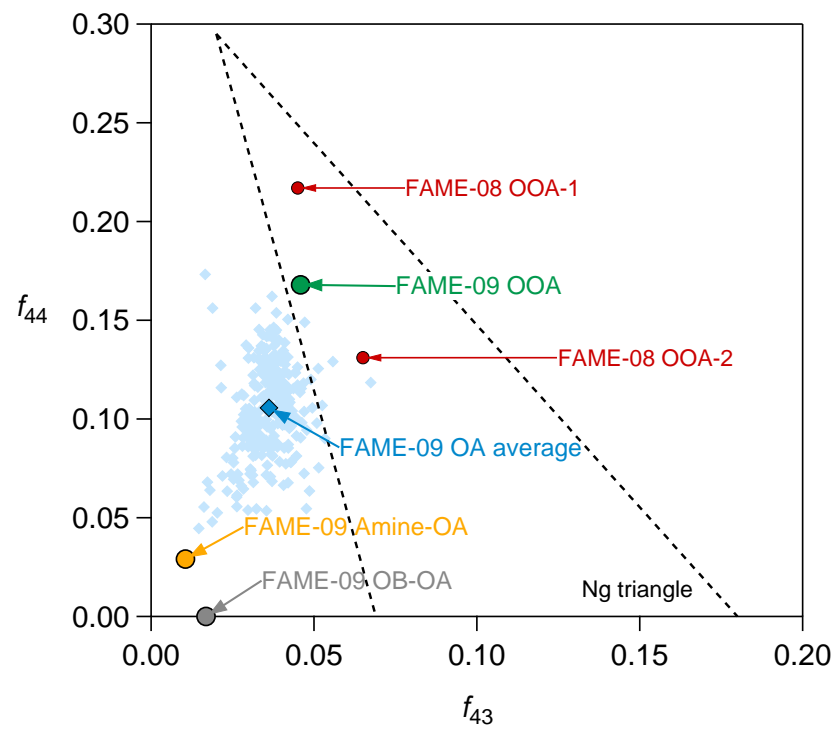

Fig. 12. Organic aerosol composition in the $\mathrm{Ng}$ et al. (2010) triangle plot: $f_{44}$ (the fraction of total organic signal due to ions at $m / z 44)$ vs. $f_{43}$. OOA during FAME-09 and FAME-08 fall within the triangle. Average bulk OA composition during FAME-09 (large blue rhombus) falls outside of the triangle due to the influence of Amine-OA and OB-OA. Small blue rhombi are $2 \mathrm{~h}$-averages of the bulk OA composition during FAME-09.

\subsection{Comparison to measurements at other sites}

FAME-09 was part of the EUCAARI intensive winter campaign. An overview of the results from the EUCAARI intensive campaigns has recently been published by Kulmala et al. (2011). The average OA concentration of $1.4 \mu \mathrm{g} \mathrm{m}^{-3}$ measured during FAME-09 was one of the lowest observed at the EUCAARI sites (average concentrations ranged from 1 to $8 \mu \mathrm{g} \mathrm{m}^{-3}$ ). Organic mass fractions (in dry, nonrefractory $\mathrm{PM}_{1}$ ) measured at the EUCAARI sites ranged from 20 to $60 \%$ (Kulmula et al, 2011); the FAME-09 organic mass fraction of $43 \%$ was thus within this observed range. The Amine-OA and OB-OA factors were unique to Finokalia. Elemental carbon (EC) concentrations measured during FAME-09 $\left(\right.$ average $\left.=0.3 \mu \mathrm{g} \mathrm{m}^{-3}\right)$ were lower than at other EUCAARI sites (e.g., average EC in Barcelona was $2.2 \mu \mathrm{g} \mathrm{m}^{-3}$, Kulmala et al., 2011) consistent with the remoteness of the site at Finokalia.

Recently, Ng et al. (2010) compiled organic aerosol data from AMS measurements in different locations and plotted $f_{44}$ as a function of $f_{43}$ for all OOA components. They found that all data clustered within a triangular region of the plot, the more oxidized LV-OOA falling in the top of the triangle and the less oxidized SV-OOA falling in the bottom of the triangle. Figure 12 shows the FAME-09 OA data in the $\mathrm{Ng}$ triangle plot. The FAME-09 OOA and the two OOA components extracted from the FAME-08 OA data (Hildebrandt et al., 2010a) fall within the LV-OOA region of the triangle ( $\mathrm{Ng}$ 
et al., 2010). The bulk OA data are outside of the triangle due to the presence of non-OOA components during FAME-09.

\section{Conclusions}

We sampled organic aerosol (OA) at Finokalia during the late winter (FAME-09) when oxidizing conditions were milder than during the early summer (FAME-08). Results from filter analysis are consistent with bulk aerosol mass spectrometer data and suggest that the OA was less oxidized in the winter than in the summer. Factor analysis on the OA mass spectra reveals that the OA sampled at Finokalia was entirely composed of OOA during the summer. Under milder oxidizing conditions in the winter, the OA is composed of similar OOA mixed with fresher OA components - one component probably associated with the burning of olive branches (OB-OA) and a second component associated with amines (Amine-OA). The most traditional primary OA component HOA was still entirely absent in the winter. This is presumably because the HOA, as opposed to OB-OA and Amine$\mathrm{OA}$, is semi-volatile and therefore evaporates and is oxidized to OOA before reaching the site.

Considering that the wintertime OOA sampled during FAME-09 exhibited a similar extent of oxidation and volatility as the summertime OOA sampled during FAME-08, it appears that the OOA at Finokalia represents an effective end-point in the oxidation of particle-phase organics from the sources influencing this site. Differences in the extent of oxidation of the bulk OA occur when fresher OA components are mixed with this OOA. The fresher OA components may age more rapidly toward OOA under the harsher oxidizing conditions in the summer.

\section{Appendix A}

\section{Positive Matrix Factorization (PMF) analysis}

\section{A1 General remarks}

The bilinear unmixing problem solved in PMF analysis is represented in matrix form by:

$\mathbf{X}=\mathbf{G F}+\mathbf{E}$

where $\mathbf{X}$ is an $m \times n$ matrix of the measured data with $m$ rows of average mass spectra (number of time periods $=m$ ) and $n$ columns of time series of each $m / z$ sampled (number of $m / z$ fit $=n) . \quad \mathbf{F}$ is a $p \times n$ matrix with $p$ factor profiles (constant mass spectra), $\mathbf{G}$ is an $m \times p$ matrix with the corresponding factor contributions, and $\mathbf{E}$ is the $m \times n$ matrix of residuals. $\mathbf{G}$ and $\mathbf{F}$ are fit to minimize the sum of the squared and uncertainty-scaled residuals (Paatero and Tapper, 1994).

Different PMF solutions can be obtained by varying the PMF settings, model parameters, and the input matrix, $\mathbf{X}$. We have found previously that the PMF solutions are mostly sensitive to the number of factors, $p$, chosen, and to the rotations induced by the "fpeak"-parameter (Hildebrandt et al., 2010a). Thus, we focus on choosing the number of factors and the rotation in the sections below. The other settings were similar as for the analysis of the FAME-08 dataset. We down-weighted the fragment at $\mathrm{m} / \mathrm{z} 44$ and the fragments linearly related to it in the fragmentation table $(\mathrm{m} / \mathrm{z}, 16,17,18$ and 28) according to the standard protocol suggested by U1brich et al. (2009). We did not add modeling uncertainty to the instrumental uncertainty, we used the default convergence criteria, and we used the most highly resolved data (3 min averages) for the PMF analysis and then performed further averaging in post-analysis of the data. We used the entire organic data matrix $\mathbf{X}(\mathrm{m} / \mathrm{z}$ 's $12 \ldots 300)$, but excluded the contributions at $m / z, 38$ and 41 as these signals were influenced by a high potassium signal (Hildebrandt et al., 2010b). We generally did not exclude OA plumes from the data matrix X except for one period ( $\sim 14: 30$ on 22 March) when an OA plume associated with a local fire resulted in OA concentrations exceeding $500 \mu \mathrm{g} \mathrm{m}^{-3}$. PMF analysis on the complete dataset (including thermodenuded and ambient data) and on the ambient only data yielded similar results. The factor time series and mass presented in this manuscript are from the analysis on the complete dataset. Finally, we chose different pseudo-random starting values for the algorithm in PMF2 (i.e., we changed the "seed"-numbers), but did not observe significant changes in our results.

\section{A2 Number of factors $(p)$}

First, we investigated the choice of different numbers of factors, $p$, with respect to ancillary data. The 1-factor PMF solution yielded a spectrum with significant contributions from $\mathrm{m} / \mathrm{z} 44$ and $m / z$ 58, which does not resemble mass spectra previously extracted from PMF analysis. The 2-factor solution resulted in one factor resembling OOA, and the corresponding time series correlated with sulfate and ammonium measured by the AMS (Table A1). The second factor in the 2-factor solution is dominated by ions at $\mathrm{m} / \mathrm{z}, 58$ and also has significant contributions at $m / z>100$ amu. This factor correlated weakly with fresh emission tracers $\left(\mathrm{EC}, \mathrm{NO}_{\mathrm{x}}\right.$, potassium, Table A1). The 3-factor solution yielded "OOA", the time series of which correlated more strongly with sulfate and ammonium than the "OOA" in the 2-factor solution (Table A2). The 3-factor solution also yielded a factor with a spectrum dominated by $m / z 58$ (probably an amine) which does not exhibit significant correlations with fresh emissions. The third factor in the 3-factor PMF solution has the largest contribution at $\mathrm{m} / \mathrm{z} 85$ and also has significant contributions at high $\mathrm{m} / \mathrm{z}(50 \%$ of the mass is due to ions at $\mathrm{m} / \mathrm{z}>120)$. This factor was strongly correlated with potassium measurements (Table A2), and the time series of this factor spiked when fires were observed from the field site (Fig. 7). Thus, we attribute this factor to fires, more specifically, the burning of olive branches (OB-OA). 


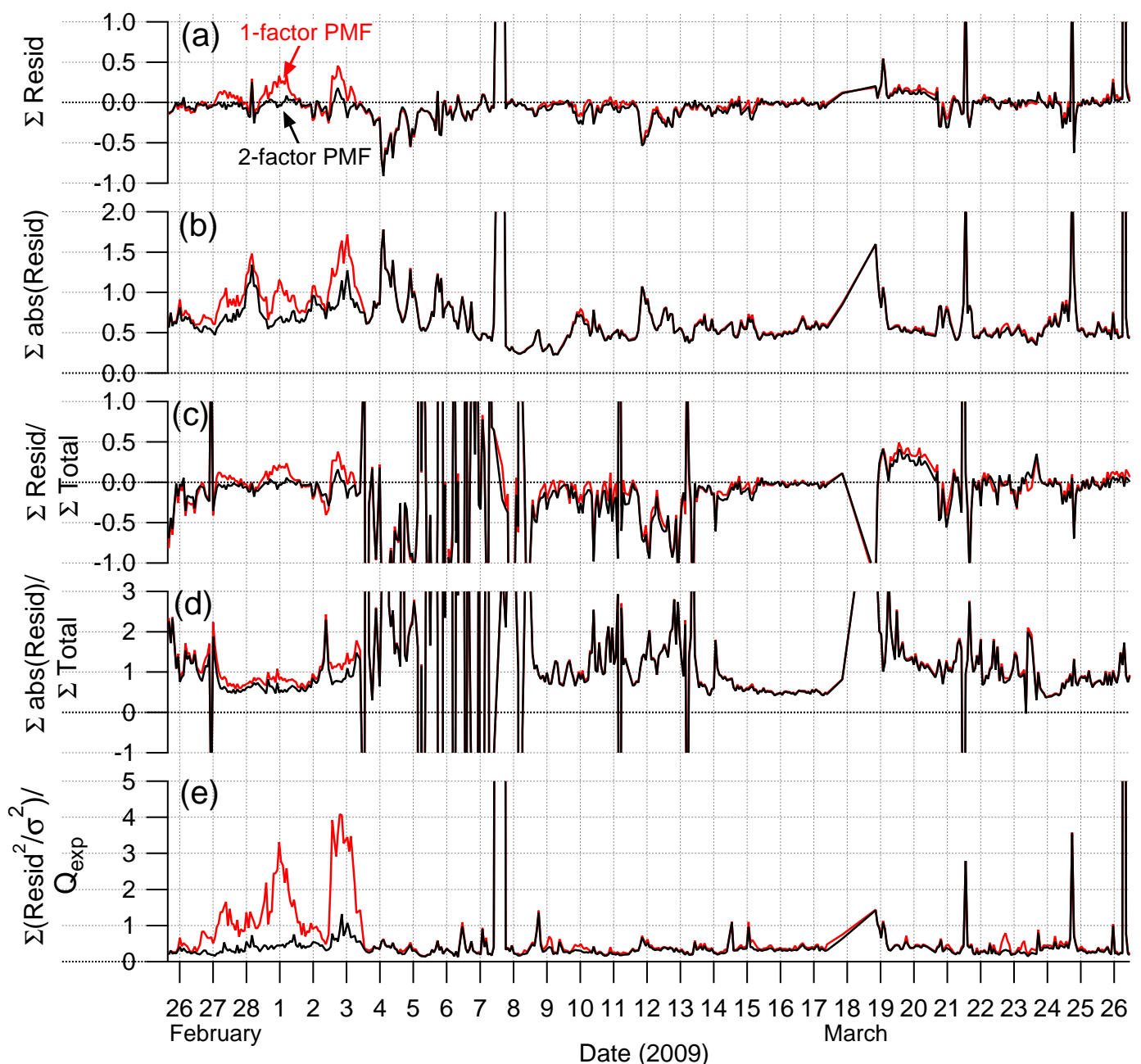

Fig. A1. Model residuals, $\mathbf{E}=\mathbf{X}-\mathbf{G F}$, for the 1-factor (red lines) and the 2-factor (black lines) PMF solutions as a function of time (summed over all $\mathrm{m} / \mathrm{z}$ 's) calculated in five different ways: (a) sum of residuals; (b) sum of the absolute value of residuals; (c) sum of residuals relative to total organics; (d) sum of absolute value of residuals relative to total organics, and (e) sum of squared, uncertainty-weighted ("scaled") residuals, $Q(t)=E(t) / S(t)$, relative to expected values, $Q \exp (t)$. Plots obtained with the PMF evaluation tool, PET, by Ulbrich et al. (2009). The structure in the residuals is decreased significantly in the $p=2$ solution compared to the $p=1$ solution, especially during the first week of the campaign. Low OA concentrations result in high values for (c) and (d) during 4-9 March.

Table A1. Correlations of PMF factors $\left(f_{i}\right)$ with ancillary data: 2-factor PMF solution.

\begin{tabular}{lccccccc}
\hline & ${ }^{\mathrm{a}} \mathrm{SO}_{4}^{2-}$ & ${ }^{\mathrm{a}} \mathrm{NH}_{4}^{+}$ & ${ }^{\mathrm{b}} \mathrm{EC}$ & $\mathrm{NO}_{\mathrm{x}}$ & $\mathrm{NO}_{\mathrm{y}}$ & ${ }^{\mathrm{a}} \mathrm{K}^{+}$ & ${ }^{\mathrm{c}} N_{\mathrm{p}}$ \\
\hline$f_{1}$ "OOA" & 0.41 & 0.46 & 0.03 & 0.01 & 0.05 & 0.02 & 0.00 \\
$f_{2}$ "Amine" & 0.05 & 0.07 & 0.21 & 0.01 & 0.24 & 0.21 & 0.06 \\
\hline
\end{tabular}

${ }^{\mathrm{a}} \mathrm{SO}_{4}^{2-}, \mathrm{NH}_{4}^{+}$and $\mathrm{K}^{+}$(potassium) measurements from AMS data. ${ }^{\mathrm{b}} \mathrm{EC}$ measurements from aethalometer data. ${ }^{\mathrm{c}} N_{\mathrm{p}}$ (Total particle number) measurements from SMPS data.

In moving from the 3-factor to the 4-factor solution, the first and second factors ("OOA" and "Amine-OA") do not change much, but the correlation of "OOA" with sulfate and ammonium becomes a bit weaker (Table A3). The "OB-OA" in the 3 -factor solution is split into two factors (factors 3 and
4 in Table A3), one dominated by ions at $m / z 29$ (factor 3 ), the other dominated by ions at $\mathrm{m} / \mathrm{z} 82$ with additional significant contributions at $\mathrm{m} / \mathrm{z} 55$ and $\mathrm{m} / \mathrm{z} 57$ (factor 4). Factor 3 has no significant correlations, and factor 4 strongly correlates with potassium and also with EC. Hence, factor 4 is most 

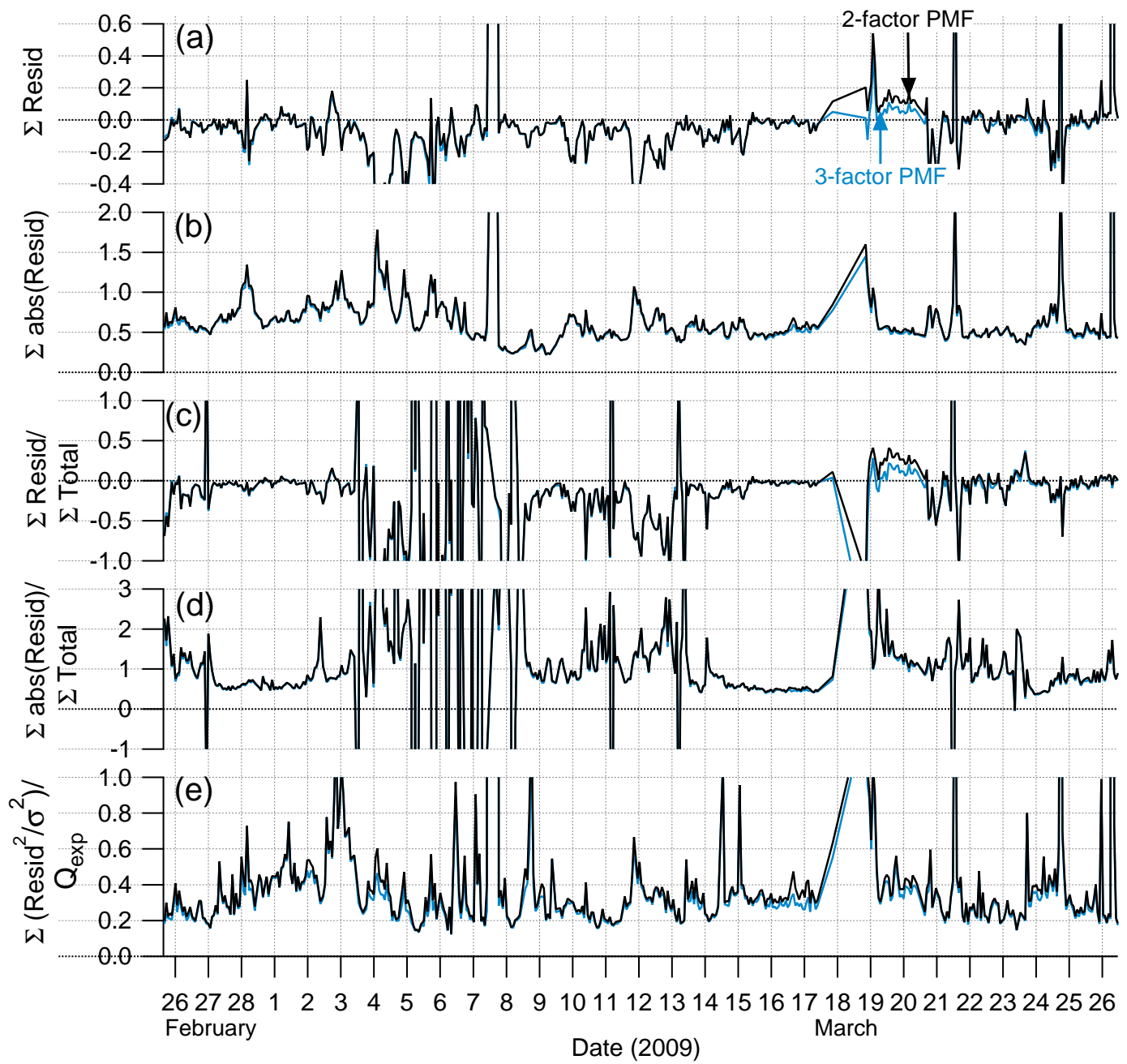

Fig. A2. Model residuals, $\mathbf{E}=\mathbf{X}-\mathbf{G F}$, for the 2-factor (black lines) and the 3-factor (blue lines) PMF solutions as a function of time (summed over all $\mathrm{m} / \mathrm{z}$ 's) calculated in five different ways: (a) sum of residuals; (b) sum of the absolute value of residuals; (c) sum of residuals relative to total organics; (d) sum of absolute value of residuals relative to total organics, and (e) sum of squared, uncertainty-weighted ("scaled") residuals, $Q(t)=E(t) / S(t)$, relative to expected values, $Q \exp (t)$. Plots obtained with the PMF evaluation tool, PET, by Ulbrich et al. (2009). The structure in the residuals is decreased somewhat in the $p=3$ solution compared to the $p=2$ solution, primarily during the period of 19-21 March. Low OA concentrations result in high values for (c) and (d) during 4-9 March.

Table A2. Correlations of PMF factors $\left(f_{i}\right)$ with ancillary data: 3-factor PMF solution.

\begin{tabular}{lccccccc}
\hline & ${ }^{\mathrm{a}} \mathrm{SO}_{4}^{2-}$ & ${ }^{\mathrm{a}} \mathrm{NH}_{4}^{+}$ & ${ }^{\mathrm{b}} \mathrm{EC}$ & $\mathrm{NO}_{\mathrm{x}}$ & $\mathrm{NO}_{\mathrm{y}}$ & ${ }^{\mathrm{a}} \mathrm{K}^{+}$ & ${ }^{\mathrm{c}} N_{\mathrm{p}}$ \\
\hline$f_{1}$ "OOA" & 0.54 & 0.58 & 0.13 & 0.01 & 0.19 & 0.05 & 0.08 \\
$f_{2}$ "Amine" & 0.05 & 0.07 & 0.03 & 0.01 & 0.05 & 0.02 & 0.00 \\
$f_{3}$ "Olive" & 0.05 & 0.10 & 0.28 & 0.01 & 0.16 & 0.57 & 0.01 \\
\hline
\end{tabular}

${ }^{a} \mathrm{SO}_{4}^{2-}, \mathrm{NH}_{4}^{+}$and $\mathrm{K}^{+}$(potassium) measurements from AMS data. ${ }^{\mathrm{b}} \mathrm{EC}$ measurements from aethalometer data. ${ }^{\mathrm{c}} N_{\mathrm{p}}$ (Total particle number) measurements from SMPS data.

likely attributable to fires and not the "HOA" typically extracted from PMF analysis. Overall, the distinction between factors 3 and 4 , and their interpretation, is ambiguous.
In addition to the ancillary data, we also evaluated mathematical diagnostics. The sum of the squared, uncertaintyweighted residuals relative to their expected values Q/Q.exp decreased by $20 \%$ from $p=1$ to $p=2$, by $8 \%$ from $p=2$ to 
Table A3. Correlations of PMF factors $\left(f_{i}\right)$ with ancillary data: 4-factor PMF solution.

\begin{tabular}{lccccccc}
\hline & ${ }^{\mathrm{a}} \mathrm{SO}_{4}^{2-}$ & ${ }^{\mathrm{a}} \mathrm{NH}_{4}^{+}$ & ${ }^{\mathrm{b}} \mathrm{EC}$ & $\mathrm{NO}_{\mathrm{x}}$ & $\mathrm{NO}_{\mathrm{y}}$ & ${ }^{\mathrm{a}} \mathrm{K}^{+}$ & ${ }^{\mathrm{c}} N_{\mathrm{p}}$ \\
\hline$f_{1}$ "OOA" & 0.53 & 0.49 & 0.15 & 0.01 & 0.18 & 0.06 & 0.03 \\
$f_{2}$ "Amine" & 0.04 & 0.06 & 0.03 & 0.00 & 0.00 & 0.02 & 0.00 \\
$f_{3}$ "Olive" & 0.01 & 0.07 & 0.00 & 0.00 & 0.01 & 0.00 & 0.09 \\
$f_{4}$ "HOA?" & 0.04 & 0.08 & 0.28 & 0.00 & 0.15 & 0.59 & 0.01 \\
\hline
\end{tabular}

${ }^{a} \mathrm{SO}_{4}^{2-}, \mathrm{NH}_{4}^{+}$and $\mathrm{K}^{+}$(potassium) measurements from AMS data. ${ }^{\mathrm{b}} \mathrm{EC}$ measurements from aethalometer data. ${ }^{\mathrm{c}} N_{\mathrm{p}}$ (Total particle number) measurements from SMPS data.

$p=3$, and by $5 \%$ from $p=3$ to $p=4$. We also analyzed the model residuals, $\mathbf{E}$, as a function of time. Structures in these residuals indicate that some OA processes and/or OA sources cannot be fully explained by the model. The structure in the model residuals could be markedly reduced by increasing the number of factors from $p=1$ to $p=2$ (Fig. A1), especially during the first week of the campaign. When further increasing the number of factors from $p=2$ to $p=3$ only a minor decrease in the structure of the model residuals, $\mathbf{E}$, could be observed (Fig. A2). An even smaller decrease in the structure of the model residuals was observed when increasing the number of factors to $p=4$ (not shown). We note that some significant structure in the residual remained even at $p=3$ and $p=4$. This suggests that some processes and/or OA sources cannot be fully explained by this mathematical model, which is based on the assumption that the measured OA mass spectra can be separated into a number of constant components.

In summary, the physical meaning of the factors can be most clearly interpreted in the 3-factor solution, and the OOA in this solution is most strongly correlated with sulfate and ammonium. Thus, considering the ancillary data, the 3factor solution is most appropriate. The mathematical diagnostics for choosing the number of factors are not as clear as the ancillary data. While the choice of moving from $p=1$ to $p=2$ is clear, the decision between $p=2$ and $p=3$ is less clear mathematically. However, as the $p=3$ solution is superior based on the physical interpretation, we conclude that the $p=3$ solution best represents our data.

\section{A3 Inducing different rotational states (fpeak)}

In contrast to the FAME-08 data set (Hildebrandt et al., 2010a), the results of the FAME-09 PMF analysis were not very sensitive to the different rotational states (fpeak). At $p=3, Q / Q \exp$ increased by only $+0.7 \%$ from fpeak $=0.0$ to fpeak $=-0.4$, which was the largest change in $Q / Q \exp$ for the fpeak values investigated here. We find that positive fpeaks increase $f_{57}$ (the fraction of the total organic signal due to fragments at $\mathrm{m} / \mathrm{z}, 57)$ in OB-OA $(1.2 \%, 1.4 \%$, $1.6 \%$ at fpeaks $-0.4,0.0,+0.4$, respectively) and also $f_{60}$ in OB-OA $(0.0 \%, 0.3 \%, 0.3 \%$ at fpeaks $-0.4,0.0,+0.4$, respectively), whereas negative fpeaks lower the $f_{58}$ in Amine-
OA $(40.7 \%, 56.4 \%, 71.6 \%$ at fpeaks $-0.4,0.0,+0.4$, respectively). The influence of fpeak on the OOA mass spectrum was relatively weak ( $f_{44}$ was $15.2 \%, 16.9 \%$ and $16.6 \%$ at fpeaks $-0.4,0.0,+0.4$, respectively). The average factor concentrations changed only moderately for different fpeaks: the average OOA concentration was $0.47 \mu \mathrm{g} \mathrm{m}^{-3}$, $0.49 \mu \mathrm{g} \mathrm{m}^{-3}$ and $0.52 \mu \mathrm{g} \mathrm{m}^{-3}$, the average OB-OA was $0.19 \mu \mathrm{g} \mathrm{m}^{-3}, 0.20 \mu \mathrm{g} \mathrm{m}^{-3}$ and $0.19 \mu \mathrm{g} \mathrm{m}^{-3}$, and the average Amine-OA concentration was $0.14 \mu \mathrm{g} \mathrm{m}^{-3}, 0.10 \mu \mathrm{g} \mathrm{m}^{-3}$ and $0.08 \mu \mathrm{g} \mathrm{m}^{-3}$ at fpeaks $-0.4,0$ and 0.4 , respectively. Thus, fpeak $=0.0$, which we chose, represents a compromise based on the factor mass spectra, and the PMF solution is quite robust with respect to the factor concentrations.

Acknowledgements. We thank Ilona Riipinen for her assistance with the aerosol evaporation model. This research was supported by the FP7 Integrated Project PEGASOS (contract number 265148). Lea Hildebrandt was supported by Graduate Research Fellowships from the National Science Foundation, the EPA STAR Program, the Teresa and H. John Heinz III Foundation and John and Claire Bertucci.

Edited by: V.-M. Kerminen

\section{References}

Aiken, A. C., DeCarlo, P. F., Kroll, J. H., Worsnop, D. R., Huffman, J. A., Docherty, K., Ulbrich, I. M., Mohr, C., Kimmel, J. R., Sueper, D., Sun, Y., Zhang, Q., Trimborn, A. M., Northway, M. J., Ziemann, P. J., Canagaratna, M. R., Alfarra, M. R., Prevot, A. S. H., Dommen, J., Duplissy, J., Metzger, A., Baltensperger, U., and Jimenez, J. L.: O/C and OM/OC ratios of primary, secondary, and ambient organic aerosols with High Resolution Time-of-Flight Aerosol Mass Spectrometry, Environ. Sci. Technol., 42, 4478-4485, 2008.

Alfarra, M. R.: Insights into atmospheric organic aerosols using an aerosol mass spectrometer, Ph.D., Chemical Engineering, University of Manchester, Manchester, 226 pp., 2004.

Allan, J. D., Delia, A. E., Coe, H., Bower, K. N., Alfarra, M. R., Jimenez, J. L., Middlebrook, A. M., Drewnick, F., Onasch, T. B., Canagaratna, M. R., Jayne, J. T., and Worsnop, D. R.: A generalised method for the extraction of chemically resolved mass spectra from aerodyne aerosol mass spectrometer data, J. Aerosol Sci., 35, 909-922, 2004. 
Cabada, J. C., Pandis, S. N., Subramanian, R., Robinson, A. L., Polidori, A., and Turpin, B.: Estimating the secondary organic aerosol contribution to $\mathrm{PM}_{2.5}$ using the EC tracer method, Aerosol Sci. Technol., 38, 140-155, 2004.

Canagaratna, M. R., Jayne, J. T., Jimenez, J. L., Allan, J. D., Alfarra, M. R., Zhang, Q., Onasch, T. B., Drewnick, F., Coe, H., Middlebrook, A. M., Delia, A., Williams, L. R., Trimborn, A. M., Northway, M. J., DeCarlo, P. F., Kolb, C. E., Davidovits, P., and Worsnop, D. R.: Chemical and microphysical characterization of ambient aerosols with the Aerodyne Aerosol Mass Spectrometer, Mass Spectrom. Rev., 26, 185-222, 2007.

Davidson, C. I., Phalen, R. F., and Solomon, P. A.: Airborne particulate matter and human health: A review, Aerosol Sci. Technol., 39, 737-749, 2005.

Drewnick, F., Hings, S. S., Alfarra, M. R., Prevot, A. S. H., and Borrmann, S.: Aerosol quantification with the Aerodyne Aerosol Mass Spectrometer: detection limits and ionizer background effects, Atmos. Meas. Tech., 2, 33-46, doi:10.5194/amt-2-332009, 2009.

Ge, X., Wexler, A. S., and Clegg, S. L.: Atmospheric amines - Part I. A review, Atmos. Environ., 45, 524-546, 2011 a.

Ge, X., Wexler, A. S., and Clegg, S. L.: Atmospheric amines Part II. Thermodynamic properties and gas/particle partitioning, Atmos. Environ., 45, 561-577, $2011 \mathrm{~b}$.

Hallquist, M., Wenger, J. C., Baltensperger, U., Rudich, Y., Simpson, D., Claeys, M., Dommen, J., Donahue, N. M., George, C., Goldstein, A. H., Hamilton, J. F., Herrmann, H., Hoffmann, T., Iinuma, Y., Jang, M., Jenkin, M. E., Jimenez, J. L., Kiendler-Scharr, A., Maenhaut, W., McFiggans, G., Mentel, Th. F., Monod, A., Prévôt, A. S. H., Seinfeld, J. H., Surratt, J. D., Szmigielski, R., and Wildt, J.: The formation, properties and impact of secondary organic aerosol: current and emerging issues, Atmos. Chem. Phys., 9, 5155-5236, doi:10.5194/acp-95155-2009, 2009.

Hildebrandt, L., Engelhart, G. J., Mohr, C., Kostenidou, E., Lanz, V. A., Bougiatioti, A., DeCarlo, P. F., Prevot, A. S. H., Baltensperger, U., Mihalopoulos, N., Donahue, N. M., and Pandis, S. N.: Aged organic aerosol in the Eastern Mediterranean: the Finokalia Aerosol Measurement Experiment - 2008, Atmos. Chem. Phys., 10, 4167-4186, doi:10.5194/acp-10-4167-2010, 2010a.

Hildebrandt, L., Kostenidou, E., Mihalopoulos, N., Worsnop, D. R., Donahue, N. M., and Pandis, S. N.: Formation of highly oxygenated organic aerosol in the atmosphere: Insights from the Finokalia Aerosol Measurement Experiments, Geophys. Res. Lett., 37, L23801, doi:10.1029/2010GL045193, 2010b.

Huffman, J. A., Docherty, K. S., Aiken, A. C., Cubison, M. J., U1brich, I. M., DeCarlo, P. F., Sueper, D., Jayne, J. T., Worsnop, D. R., Ziemann, P. J., and Jimenez, J. L.: Chemically-resolved aerosol volatility measurements from two megacity field studies, Atmos. Chem. Phys., 9, 7161-7182, doi:10.5194/acp-9-71612009, 2009.

IPCC: Climate Change 2007 - The Physical Science Basis., Contribution of Working Group I to the Fourth Assessment Report of the IPCC, 2007.

Jimenez, J. L., Canagaratna, M. R., Donahue, N. M., Prevot, A. S. H., Zhang, Q., Kroll, J. H., DeCarlo, P. F., Allan, J. D., Coe, H., Ng, N. L., Aiken, A. C., Docherty, K. D., Ulbrich, I. M., Grieshop, A. P., Robinson, A. L., Duplissy, J., Smith, J. D., Wil- son, K. R., Lanz, V. A., Hueglin, C., Sun, Y. L., Tian, J., Laaksonen, A., Raatikainen, T., Rautiainen, J., Vaattovaara, P., Ehn, M., Kulmala, M., Tomlinson, J. M., Collins, D. R., Cubison, M. J., Dunlea, E. J., Huffman, J. A., Onasch, T. B., Alfarra, M. R., Williams, P. I., Bower, K., Kondo, Y., Schneider, J., Drewnick, F., Borrmann, S., Weimer, S., Demerjian, K., Salcedo, D., Cottrell, L., Griffin, R., Takami, A., Miyoshi, T., Hatakeyama, S., Shimono, A., Sun, J. Y., Zhang, Y. M., Dzepina, K., Kimmel, J. R., Sueper, D., Jayne, J. T., Herndon, S. C., Trimborn, A. M., Williams, L. R., Wood, E. C., Kolb, C. E., Baltensperger, U., and Worsnop, D. R.: Evolution of organic aerosol in the atmosphere, Science, 326, 1525-1529, doi:10.1126/science.1180353, 2009.

Kalberer, M., Paulsen, D., Sax, M., Steinbacher, M., Dommen, J., Prevot, A. S. H., Fisseha, R., Weingartner, E., Frankevich, V., Zenobi, R., and Baltensperger, U.: Identification of polymers as major components of atmospheric organic aerosols, Science, 303, 1659-1662, doi:10.1126/science.1092185, 2004.

Kanakidou, M., Tsigaridis, K., Dentener, F. J., and Crutzen, P. J.: Human-activity-enhanced formation of organic aerosols by biogenic hydrocarbon oxidation, J. Geophys. Res.-Atmos., 105, 9243-9254, 2000.

Kostenidou, E., Pathak, R. K., and Pandis, S. N.: An algorithm for the calculation of secondary organic aerosol density combining AMS and SMPS data, Aerosol Sci. Technol., 41, 1002-1010, 2007.

Koulouri, E., Saarikoski, S., Theodosi, C., Markaki, Z., Gerasopoulos, E., Kouvarakis, G., Makela, T., Hillamo, R., and Mihalopoulos, N.: Chemical composition and sources of fine and coarse aerosol particles in the Eastern Mediterranean, Atmos. Environ., 42, 6542-6550, doi:10.1016/j.atmosenv.2008.04.010, 2008.

Kulmala, M., Asmi, A., Lappalainen, H. K., Carslaw, K. S., Pöschl, U., Baltensperger, U., Hov, Ø., Brenquier, J.-L., Pandis, S. N., Facchini, M. C., Hansson, H.-C., Wiedensohler, A., and O'Dowd, C. D.: Introduction: European Integrated Project on Aerosol Cloud Climate and Air Quality interactions (EUCAARI) - integrating aerosol research from nano to global scales, Atmos. Chem. Phys., 9, 2825-2841, doi:10.5194/acp-9-2825-2009, 2009.

Kulmala, M., Asmi, A., Lappalainen, H. K., Baltensperger, U., Brenguier, J.-L., Facchini, M. C., Hansson, H.-C., Hov, Ø., O'Dowd, C. D., Pöschl, U., Wiedensohler, A., Boers, R., Boucher, O., de Leeuw, G., Denier van den Gon, H., Feichter, J., Krejci, R., Laj, P., Lihavainen, H., Lohmann, U., McFiggans, G., Mentel, T., Pilinis, C., Riipinen, I., Schulz, M., Stohl, A., Swietlicki, E., Vignati, E., Amann, M., Amann, M., Alves, C., Arabas, S., Artaxo, P., Beddows, D. C. S., Bergström, R., Beukes, J. P., Bilde, M., Burkhart, J. F., Canonaco, F., Clegg, S., Coe, H., Crumeyrolle, S., D’Anna, B., Decesari, S., Gilardoni, S., Fischer, M., Fjæraa, A. M., Fountoukis, C., George, C., Gomes, L., Halloran, P., Hamburger, T., Harrison, R. M., Herrmann, H., Hoffmann, T., Hoose, C., Hu, M., Hõrrak, U., Iinuma, Y., Iversen, T., Josipovic, M., Kanakidou, M., KiendlerScharr, A., Kirkevåg, A., Kiss, G., Klimont, Z., Kolmonen, P., Komppula, M., Kristjnsson, J.-E., Laakso, L., Laaksonen, A., Labonnote, L., Lanz, V. A., Lehtinen, K. E. J., Makkonen, R., McMeeking, G., Merikanto, J., Minikin, A., Mirme, S., Morgan, W. T., Nemitz, E., O’Donnell, D., Panwar, T. S., Pawlowska, H., Petzold, A., Pienaar, J. J., Pio, C., Plass-Duelmer, C., Prévôt, A. S. H., Pryor, S., Reddington, C. L., Roberts, G., Rosen- 
feld, D., Schwarz, J., Seland, Ø., Sellegri, K., Shen, X. J., Shiraiwa, M., Siebert, H., Sierau, B., Simpson, D., Sun, J. Y., Topping, D., Tunved, P., Vaattovaara, P., Vakkari, V., Veefkind, J. P., Visschedijk, A., Vuollekoski, H., Vuolo, R., Wehner, B., Wildt, J., Woodward, S., Worsnop, D. R., van Zadelhoff, G.-J., Zardini, A. A., Zhang, K., van Zyl, P. G., Kerminen, V.-M., S. Carslaw, K., and Pandis, S. N.: General overview: European Integrated project on Aerosol Cloud Climate and Air Quality interactions (EUCAARI) - integrating aerosol research from nano to global scales, Atmos. Chem. Phys. Discuss., 11, 17941-18160, doi:10.5194/acpd-11-17941-2011, 2011.

Lanz, V. A., Alfarra, M. R., Baltensperger, U., Buchmann, B., Hueglin, C., and Prévôt, A. S. H.: Source apportionment of submicron organic aerosols at an urban site by factor analytical modelling of aerosol mass spectra, Atmos. Chem. Phys., 7, 1503-1522, doi:10.5194/acp-7-1503-2007, 2007.

Lanz, V. A., Alfarra, M. R., Baltensperger, U., Buchmann, B., Hueglin, C., Szidat, S., Wehrli, M. N., Wacker, L., Weimer, S., Caseiro, A., Puxbaum, H., and Prevot, A. S. H.: Source attribution of submicron organic aerosols during wintertime inversions by advanced factor analysis of aerosol mass spectra, Environ. Sci. Technol., 42, 214-220, 2008.

Lanz, V. A., Prévôt, A. S. H., Alfarra, M. R., Weimer, S., Mohr, C., DeCarlo, P. F., Gianini, M. F. D., Hueglin, C., Schneider, J., Favez, O., D'Anna, B., George, C., and Baltensperger, U.: Characterization of aerosol chemical composition with aerosol mass spectrometry in Central Europe: an overview, Atmos. Chem. Phys., 10, 10453-10471, doi:10.5194/acp-10-10453-2010, 2010.

Lee, B.-H.: Volatility of atmospheric organic aerosol, Doctor of Philosophy, Chemical Engineering, Carnegie Mellon University, Pittsburgh, 155 pp., 2010.

Lee, B. H., Kostenidou, E., Hildebrandt, L., Riipinen, I., Engelhart, G. J., Mohr, C., DeCarlo, P. F., Mihalopoulos, N., Prevot, A. S. H., Baltensperger, U., and Pandis, S. N.: Measurement of the ambient organic aerosol volatility distribution: application during the Finokalia Aerosol Measurement Experiment (FAME2008), Atmos. Chem. Phys., 10, 12149-12160, doi:10.5194/acp10-12149-2010, 2010.

Loo, B. W. and Cork, C. P.: Development of a high efficiency virtual impactor, Aerosol Sci. Technol., 9, 167-176, 1988.

Mihalopoulos, N., Stephanou, E., Kanakidou, M., Pilitsidis, S., and Bousquet, P.: Tropospheric aerosol ionic composition in the Eastern Mediterranean region, Tellus B, 49, 314-326, 1997.

Morgan, W. T., Allan, J. D., Bower, K. N., Highwood, E. J., Liu, D., McMeeking, G. R., Northway, M. J., Williams, P. I., Krejci, R., and Coe, H.: Airborne measurements of the spatial distribution of aerosol chemical composition across Europe and evolution of the organic fraction, Atmos. Chem. Phys., 10, 4065-4083, doi:10.5194/acp-10-4065-2010, 2010.

Ng, N. L., Canagaratna, M. R., Zhang, Q., Jimenez, J. L., Tian, J., Ulbrich, I. M., Kroll, J. H., Docherty, K. S., Chhabra, P. S., Bahreini, R., Murphy, S. M., Seinfeld, J. H., Hildebrandt, L., Donahue, N. M., DeCarlo, P. F., Lanz, V. A., Prévôt, A. S. H., Dinar, E., Rudich, Y., and Worsnop, D. R.: Organic aerosol components observed in Northern Hemispheric datasets from Aerosol Mass Spectrometry, Atmos. Chem. Phys., 10, 46254641, doi:10.5194/acp-10-4625-2010, 2010.

Ng, N. L., Canagaratna, M. R., Jimenez, J. L., Zhang, Q., Ulbrich, I. M., and Worsnop, D. R.: Real-time methods for estimating organic component mass concentrations from aerosol mass spectrometer data, Environ. Sci. Technol., 45, 910-916, 2011.

Paatero, P. and Tapper, U.: Positive Matrix Factorization: a nonnegative factor model with optimal utilization of error estimates of data values, Environmetrics, 5, 111-126, 1994.

Pankow, J. F.: An absorption model of the gas/aerosol partitioning involved in the formation of secondary organic aerosol. Atmos. Environ., 28, 189-193, 1994.

Pikridas, M., Bougiatioti, A., Hildebrandt, L., Engelhart, G. J., Kostenidou, E., Mohr, C., Prévôt, A. S. H., Kouvarakis, G., Zarmpas, P., Burkhart, J. F., Lee, B.-H., Psichoudaki, M., Mihalopoulos, N., Pilinis, C., Stohl, A., Baltensperger, U., Kulmala, M., and Pandis, S. N.: The Finokalia Aerosol Measurement Experiment - 2008 (FAME-08): an overview, Atmos. Chem. Phys., 10, 6793-6806, doi:10.5194/acp-10-6793-2010, 2010.

Pikridas, M., Riipinen, I., Hildebrandt, L., Kostenidou, E., Manninen, H. E., Mihalopoulos, N., Kalivitis, N., Burkhart, J. F., Stohl, A., Kulmala, M., and Pandis, S. N.: New particle formation at a remote site in the Eastern Mediterranean, J. Geophys. Res.Atmos., submitted, 2011.

Pope, C. A. and Dockery, D. W.: Health effects of fine particulate air pollution: Lines that connect, J. Air Waste Manage., 56, 709742, 2006.

Prevot, A. S. H., Lanz, V. A., Canonaco, F., Nemitz, E., Aijälä, M., Allan, J., Baltensperger, U., Canagaratna, M., Carbone, S., Coe, H., Dall`Osto, M., DeCarlo, P., di Marco, C., Donahue, N. M., Ehn, M., Eriksson, A., Hildebrandt, L., Hillamo, R., Freney, E., Jimenez, J.-L., Junninen, H., Kiendler-Scharr, A., Kostenidou, E., Kulmala, M., Mensah, A., Mohr, C., Ng, S., O`Dowd, C. D., Ortega, A., Ovadnevaite, J., Pandis, S., Poulain, L., Raatikainen, T., Saarikoski, S., Sellegri, K., Sueper, D., Swietlicki, E., Tiitta, P., Ulbrich, I. M., and Worsnop, D.: Overview of organic PM $_{1}$ composition and sources in Europe (EMEP/EUCAARI campaigns in 2008-2009) determined by factor analysis of aerosol mass spectrometry (AMS) data, Atmos. Chem. Phys. Discuss., in preparation, 2011.

Rehbein, P. J. G., Jeong, C.-H., McGuire, M. L., Yao, X., Corbin, J. C., and Evans, G. J.: Cloud and fog processing enhanced gas-toparticle partitioning of trimethylamine, Environ. Sci. Technol., 45, 4346-4352, 2011.

Riipinen, I., Pierce, J. R., Donahue, N. M., and Pandis, S. N.: Equilibration time scales of organic aerosol inside thermodenuders: Kinetic versus equilibrium thermodynamics, Atmos. Environ., 44, 597-607, 2010.

Robinson, A. L., Donahue, N. M., and Rogge, W. F.: Photochemical oxidation and changes in molecular composition of organic aerosol in the regional context, J. Geophys. Res., 11, D03302, doi:10.1029/2005JD006265, 2006.

Robinson, A. L., Donahue, N. M., Shrivastava, M. K., Weitkamp, E. A., Sage, A. M., Grieshop, A. P., Lane, T. E., Pierce, J. R., and Pandis, S. N.: Rethinking organic aerosols: Semivolatile emissions and photochemical aging, Science, 315, 1259-1262, 2007.

Sciare, J., Oikonomou, K., Cachier, H., Mihalopoulos, N., Andreae, M. O., Maenhaut, W., and Sarda-Estève, R.: Aerosol mass closure and reconstruction of the light scattering coefficient over the Eastern Mediterranean Sea during the MINOS campaign, Atmos. Chem. Phys., 5, 2253-2265, doi:10.5194/acp-5-2253-2005, 2005.

Seinfeld, J. H. and Pandis, S. N.: Atmospheric Chemistry and 
Physics, Second Edition, John Wiley \& Sons, Hoboken, 2006.

Smith, J. N., Barsanti, K. C., Friedli, H. R., Ehn, M., Kulmala, M., Collins, D. R., Scheckman, J. H., Williams, B. J., and McMurry, P. H.: Observations of aminium salts in atmospheric nanoparticles and possible climatic implications, P. Nat. A. Sci., 107, 6634-6639, 2010.

Stohl, A., Hittenberger, M., and Wotawa, G.: Validation of the Lagrangian particle dispersion model FLEXPART against large scale tracer experiments, Atmos. Environ., 32, 4245-4264, 1998.

Sun, Y.-L., Zhang, Q., Schwab, J. J., Demerjian, K. L., Chen, W.N., Bae, M.-S., Hung, H.-M., Hogrefe, O., Frank, B., Rattigan, O. V., and Lin, Y.-C.: Characterization of the sources and processes of organic and inorganic aerosols in New York city with a high-resolution time-of-flight aerosol mass apectrometer, Atmos. Chem. Phys., 11, 1581-1602, doi:10.5194/acp-11-15812011, 2011.

Takami, A., Miyoshi, T., Shimono, A., and Hatakeyama, S.: Chemical composition of fine aerosol measured by AMS at Fukue Island, Japan during APEX period, Atmos. Environ., 39, 49134924, 2005.

Ulbrich, I. M., Canagaratna, M. R., Zhang, Q., Worsnop, D. R., and Jimenez, J. L.: Interpretation of organic components from Positive Matrix Factorization of aerosol mass spectrometric data, Atmos. Chem. Phys., 9, 2891-2918, doi:10.5194/acp-9-2891-2009, 2009.
Violaki, K. and Mihalopoulos, N.: Water-soluble organic nitrogen (WSON) in size-segregated atmospheric particles over the Eastern Mediterranean, Atmos. Environ., 44, 4339-4345, 2010.

Watson, J. G.: Visibility: Science and regulation, J. Air Waste Manage., 52, 628-713, 2002.

Zhang, Q., Jimenez, J. L., Canagaratna, M. R., Allan, J. D., Coe, H., Ulbrich, I., Alfarra, M. R., Takami, A., Middlebrook, A. M., Sun, Y. L., Dzepina, K., Dunlea, E., Docherty, K., DeCarlo, P. F., Salcedo, D., Onasch, T., Jayne, J. T., Miyoshi, T., Shimono, A., Hatakeyama, S., Takegawa, N., Kondo, Y., Schneider, J., Drewnick, F., Borrmann, S., Weimer, S., Demerjian, K., Williams, P., Bower, K., Bahreini, R., Cottrell, L., Griffin, R. J., Rautiainen, J., Sun, J. Y., Zhang, Y. M., and Worsnop, D. R.: Ubiquity and dominance of oxygenated species in organic aerosols in anthropogenically-influenced Northern Hemisphere midlatitudes, Geophys. Res. Lett., 34, L13801, doi:10.1029/2007gl029979, 2007. 